\title{
The emerging roles of orphan nuclear receptors in prostate cancer
}

\author{
Dinglan $\mathrm{Wu}^{\mathrm{a}, \#}$, Alyson Cheung ${ }^{\mathrm{a}, \#}$, Yuliang Wang ${ }^{\mathrm{a}}$, Shan $\mathrm{Yu}^{\mathrm{a}, *}$, and Franky L. Chan ${ }^{\mathrm{a}, *}$ \\ ${ }^{a}$ School of Biomedical Sciences, Faculty of Medicine, The Chinese University of Hong \\ Kong, Shatin, Hong Kong, China
}

Keywords: Orphan nuclear receptors, metabolism, androgen receptor signaling, prostate cancer, castration resistance

\#Dinglan Wu and \#Alyson Cheung contributed equally to this article.

Correspondence addressed to:

*Franky L. Chan and *Shan Yu, School of Biomedical Sciences, Lo Kwee-Seong Integrated Biomedical Sciences Building, The Chinese University of Hong Kong, Shatin, New Territories, Hong Kong, China; Phone: (852) 3943 6841; Fax: (852) 2603 5123; Email: franky-chan@cuhk.edu.hk; yushan771@hotmail.com 


\begin{abstract}
Orphan nuclear receptors are members of the nuclear receptor (NR) superfamily and are so named because their endogenous physiological ligands are either unknown or may not exist. Because of their important regulatory roles in many key physiological processes, dysregulation of signalings controlled by these receptors is associated with many diseases including cancer. Over years, studies of orphan NRs have become an area of great interest because their specific physiological and pathological roles have not been well-defined, and some of them are promising drug targets for diseases. The recently identified synthetic small molecule ligands, acting as agonists or antagonists, to these orphan NRs not only help to understand better their functional roles but also highlight that the signalings mediated by these ligand-independent NRs in diseases could be therapeutically intervened. This review is a summary of the recent advances in elucidating the emerging functional roles of orphan NRs in cancers, especially prostate cancer. In particular, some orphan NRs, ROR $\gamma$, TR2, TR4, COUP-IFII, ERRa, DAX1 and SHP, exhibit crosstalk or interference with androgen receptor (AR) signaling in either normal or malignant prostatic cells, highlighting their involvement in prostate cancer progression as androgen and AR signaling pathway play critical roles in this process. We also propose that a better understanding of the mechanism of actions of these orphan NRs in prostate gland or prostate cancer could help to evaluate their potential value as therapeutic targets for prostate cancer.
\end{abstract}


Abstract

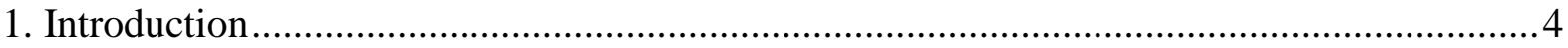

2. Nuclear receptors and orphan nuclear receptors ........................................................ 4

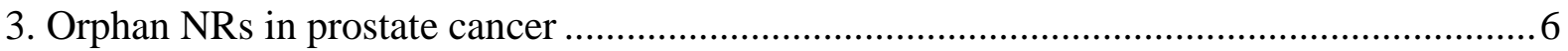

3.1 TR2, TR4

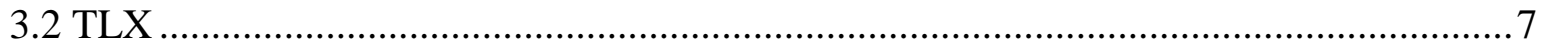

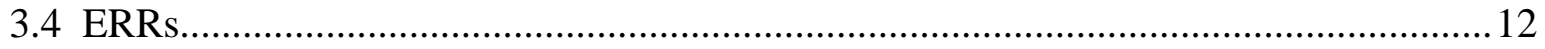

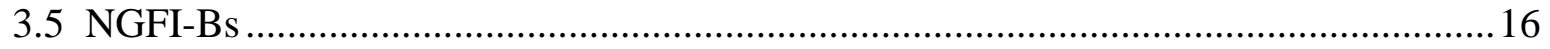

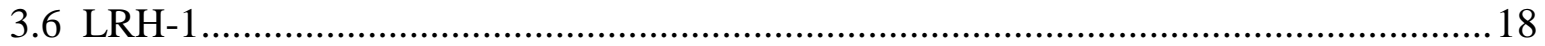

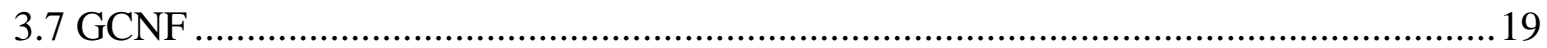

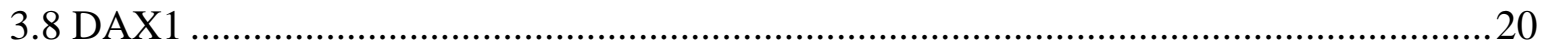

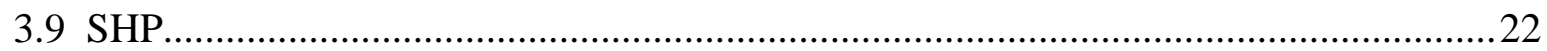

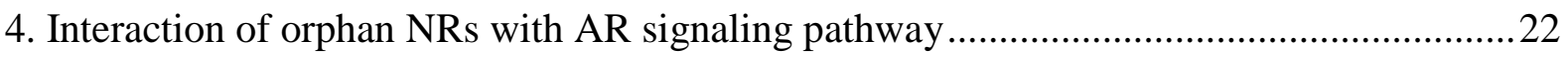

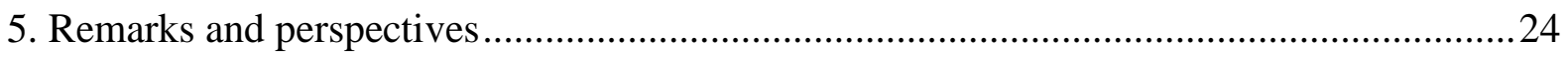

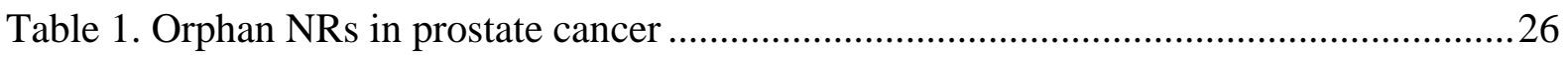

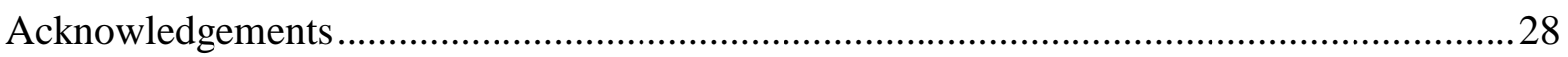

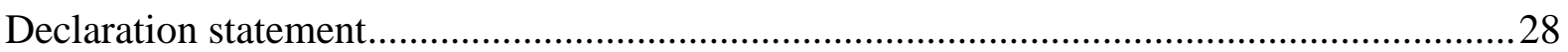

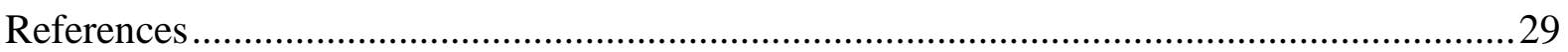

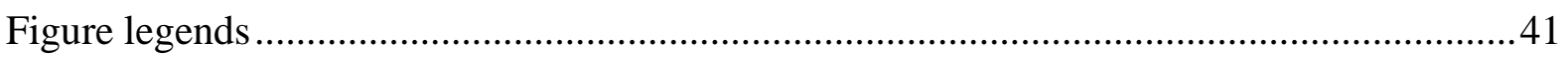




\section{Introduction}

Prostate cancer is the most frequently diagnosed cancer among males in most economically developed countries. The American Cancer Society estimates that in 2016, there will be 180,890 newly diagnosed cases and 26,120 deaths due to prostate cancer in the United States, making it the second leading cause of cancer death in men (1). Recent statistics indicates that its incidence rate is also rapidly increasing in China (2). The majority of newly diagnosed (about $85 \%$ ) prostate cancers are localized to prostate gland and treatment options for primary cancers include active surveillance, radical prostatectomy and external beam radiotherapy. However, the natural history of prostate cancer is threatening once it progresses to the fatal invasive or metastatic disease. Patients with metastatic or high-risk localized disease are commonly treated with hormone therapy (androgen-deprivation therapy ADT or androgen receptor/AR-axis-targeted therapy) targeting to AR signaling. Suppression of AR signaling can be achieved by means of surgical or chemical castration to reduce androgen levels using luteinizing hormone-releasing hormone agonists (LHRHa) or androgen biosynthesis inhibitor, and blocking of AR activity using antiandrogens. Although initial responses to ADT are highly favorable for most patients, it can only last for an average of 1820 months after treatments. The disease inevitably becomes unresponsive to androgen blockade and progresses to the fatal metastatic castration-resistant prostate cancer (CRPC). Patients with metastatic CRPC have only a median survival period of about 1-2 years (3).

\section{Nuclear receptors and orphan nuclear receptors}

Nuclear receptors (NRs) constitute a superfamily of DNA-binding transcription factors, comprising the ligand-regulated (or hormone NRs) and ligand-independent members (orphan NRs), which can both activate and repress target gene expression by directly binding to specific genomic DNA sequences or indirectly via protein-protein interaction with other DNA-bound transcription factors, such as specificity proteins (Sp) and activating protein-1 
(AP-1) (4). Among the total 48 members of human NRs, 25 receptors are classified as orphan NRs or orphan receptors either because their endogenous physiological ligands have not been identified so far or their transactivation is ligand-independent. Some members originally classified as orphan NRs, including retinoid X receptors (RXRs) and peroxisome proliferatoractivated receptors (PPARs), are re-classified as "adopted orphan NRs" since some cellular metabolites or biomolecules have been identified as weak ligands to these NRs (5) (Figure 1).

In general, all NRs share a common conserved modular structure: activation domain AF-1 at the N-terminus, central DNA-binding domain (DBD), C-terminal ligand-binding domain (LBD) and the second activation domain AF-2. DBD is the most conserved domain with two zinc fingers that allow the binding of NRs to specific DNA responsive elements. NRs bind to these responsive elements, which are usually composed of hexameric sequence AGAACA-like or AGGTCA-like motifs, as monomer, homodimer or heterodimer. The LBD and AF-2 domains mediate functions including ligand-dependent transcriptional activation, coregulator binding and subcellular localization. Three-dimensional structural study reveals that the LBD consists of $12 \alpha$-helices with a hydrophobic pocket into which the ligand fits. The last C-terminal helical segment, helix-12 (H12) serves as a lid to the ligand-binding pocket and repositions for coregulator binding when there is ligand engagement. For the constitutively activated and ligand-independent orphan NRs, H12 also undergoes specific repositioning, determines the interaction between these NRs and their coactivators.

NRs play important regulatory roles virtually in all biological processes including development, embryogenesis, differentiation and maintenance of homeostasis. Dysregulation of signaling pathways controlled by NRs are involved in many diseases, including diabetes and cancer. Accruing evidences in recent years strongly suggest that orphan NRs play important roles in cancer development and progression as shown by their altered expressions and dysregulated signaling pathways involved in multiple cancers $(6,7)$. Although these orphan NRs are constitutively active and independent of any physiological ligands, there are 
increasing studies showing that orphan NRs are druggable and regarded as prospective novel cancer drug targets (8), as evidenced by some synthetic or natural compounds which can directly bind to these orphan NRs and modulate their activities. In this review, we summarized the emerging roles of orphan NRs in prostate cancer.

\section{Orphan NRs in prostate cancer}

Within the orphan NR subgroup, half of the members have been studied so far in prostate cancer.

\subsection{TR2, TR4}

The human testicular orphan nuclear receptor 2 (TR2, NR2C1; also called TR2-11) and its closely related homolog TR4 (NR2C2; also called TAK) were originally cloned from the testis and prostate cDNA libraries using DNA probe containing the DBD corresponding to the DBD of GR, PR and ER $(9,10)$. TR2 is abundantly expressed in the androgen-sensitive rat ventral prostate and seminal vesicles, with its mRNA level further increased by castration ( 9 , 10). Among the different TR2 spliced variants cloned, the longest TR2-11 variant is the major form expressed in prostate (11). It is believed that TR2 play regulatory roles in the male reproductive system (11). The $T R 2$ gene is located at human chromosome $12 \mathrm{q} 22$, a region where chromosomal loss occurs frequently in various tumors (12). However, its contribution to human malignancy is still unclear. Overexpression of TR2 in breast cancer cells can inhibit estrogen-stimulated cell growth by cell-cycle arrest and suppress ER-mediated transcription via a mechanism of direct protein-protein interaction with ER (13). TR2 can modulate androgen actions in prostate cancer cells via its suppression of AR-mediated transactivation by its interaction with $\mathrm{AR}$, whereas in reverse androgens can also repress the expression of TR2 $(14,15)$. These studies suggest that TR2 may perform an anti-proliferative role in hormone-sensitive breast and prostate cancers via its direct repression on ER and AR signaling. 
Besides sharing a similar tissue expression pattern with TR2 in prostate and testis, TR4 is also highly expressed in central nervous system. TR4 binds to its targets via forming a homodimer or a heterodimer with TR2. Transgenic TR4 knockout mice show abnormalities in spermatogenesis and developmental defects in the reproductive and central nervous systems in both genders (16). Moreover, TR $4^{-/-}$-null mice exhibit increased genome instability and defective oxidative stress defense, indicating that TR4 may play a role in premature senescence and tumor initiation (17). TR4, like TR2, can directly interact ER, which results in inhibition of the homodimerization of ER and interruption of its binding to the estrogen response elements (ERE) in the promoters of genes involved in ER-mediated cell proliferation in breast cancer cells (18). The association between TR4 and prostate cancer has been observed. TR4 expression is shown to be up-regulated in prostate cancer with higher expression in high Gleason-scored lesions (19) and patients with biochemical recurrence after radiotherapy (20). In vitro and in vivo functional analyses reveal that TR4 can promote invasion and metastasis of prostate cancer cells through transactivation of CCL2/CCR2 axis (19). TR4 is also observed to be highly expressed in prostate cancer stem cells and associated with chemoresistance in prostate cancer (21).

\subsection{TLX}

TLX (NR2E1; also called TLL) was initially identified as a vertebrate homolog of Drosophila terminal-gap gene tailless (tll), which is essential for pattern formation in Drosophila embryogenesis (22). Human TLX was identified in a search of hypothetical tumor suppressor and mapped to a common deletion region on chromosome 6q2 in human lymphoid leukemia (23). Studies from gene knockout mice show that TLX performs essential roles in invertebrate and vertebrate brain development. It was also shown that TLX was critical for regulation of self-renewal and maintenance of embryonic and adult neural stem cells (NSCs) (24). TLX caught attention from cancer biologists that it may play a role in the development of in a number of brain cancers, as shown by evidences that TLX was up- 
regulated in astrocytomas, glioblastoma, high-grade gliomas and neuroblastoma (25-27), and negatively correlated to the survival of neuroblastoma patients (27). TLX promotes the progression of brain tumors depending on its capacity on maintaining self-renewing of brain tumor stem cells (BTSCs). Transgenic overexpression of TLX in mice significantly induces NSC expansion and leads to the initiation of glioma-like lesions and gliomas (25). In vivo lineage tracing shows that $\mathrm{TLX}^{+}$cells are BTSCs, and inducible inactivation of TLX in brain tumors results in the loss of self-renewal of BTSCs and prolong survival (28). Knockdown of TLX in tumorigenic human glioblastoma stem cells (GSCs) can inhibit the in vivo tumorigenicity and prolong the survival of tumor-bearing mice by targeting to DNA hydroxylase ten-eleven-translocation 3 (TET3) (29). TLX promotes the development and progression of brain tumors not only by stimulating self-renewal of BTSCs but also through its proangiogenic function. Mechanistic study shows that TLX binds to the promoters of Oct4 and MMP-2, therefore augments the gene transcription and promotes proliferation and migration capabilities of tumor spheres in neuroblastoma (27). Moreover, TLX expression is induced upon hypoxia via its interaction with von Hippel-Lindau protein (pVHL), an ubiquitin ligase, which stabilizes HIF- $\alpha$, and thereby enhances the VEGF-promoter activity to induce angiogenesis (30). However, the study of TLX in other cancer types is limited.

Recently, TLX has been demonstrated to play critical roles in counteracting oncogeneinduced senescence in cancer carcinogenesis $(31,32)$. Oncogene-induced senescence (OIS) is considered as a key barrier in tumorigenesis. Overcoming of this process, which involves two main pathways mediated by some tumor suppressor genes (including p19 $\mathrm{ARF} / \mathrm{p} 53 / \mathrm{p} 21^{\mathrm{WAF} 1 / \mathrm{CIP} 1}$ and $\mathrm{p} 16^{\mathrm{INK} 4 \mathrm{a}} / \mathrm{pRb}$ ), is a critical step in premalignant and advanced malignant development of cancer. PTEN is one of the most frequently altered tumor suppressors in prostate cancer, with up to $70 \%$ of primary prostate tumors showing loss or alterations in at least one PTEN allele. Transgenic studies show that genetic deletion of Pten in mouse prostate causes premature senescence in vivo, termed as Pten loss-induced cellular senescence (PICS). However, the 
PICS can be bypassed by concomitant genetic inactivation of other tumor suppressor gene or activation of oncogene, such as p53 (33) and Her2 (34) with PTEN in the prostate. Recently, we show that TLX can play an oncogenic role in overcoming the OIS and PICS in prostate cancer cells (32). Immunohistochemistry of TLX in prostate tissue array data show that it exhibits an up-regulated expression pattern in advanced prostate cancer, and inhibition of it could significantly induce premature cellular senescence in prostate cancer cells, while enhancement of its activity could facilitate prostatic epithelial cells to escape oncogeneinduced senescence induced by either activated oncogene H-Ras (G12V) or knockdown of tumor suppressor PTEN, via a mechanism of direct but differential transcriptional regulation of two senescence-associated genes, repression of CDKN1A (p21) and transactivation of SIRT1, suggesting that TLX may play a role in prostate cancer initiation and progression (32) (Figure 2).

It is worth noting that senescence not only can act as a tumor suppressor mechanism but also promote tumor progression. In vitro and in vivo studies show that long-term androgen depletion could induce senescence of prostate cancer cells. However, these growth-arrest senescent but non-apoptotic cells may lead to incomplete tumor regression and contribute to subsequent development of CRPC through modulation of the tissue microenvironment, as evidenced by the upregulation of expression of vimentin and increase of neuroendocrine-like cell population after $\operatorname{ADT}(35,36)$. On the other hand, increasing evidence indicates the senescent cells confer a microenvironment that can provoke immune response, through which the senescent tumor cell and non-senescent tumor cells can be eliminated (37). Studies of in vitro and in vivo CRPC models show that these quiescent senescent cells, which are resistant to ADT, share some common features with cancer stem cells (38). The role of TLX as demonstrated in NSCs and BTSCs also suggest that TLX may play similar role in the regulation of cancer stem cells in other cancer types. Our unpublished data also showed that TLX could promote both self-renewal and maintenance of prostate cancer stem cells. 
However, its specific role in prostate tumorigenesis and the associated signaling pathway still unclear and it needs further investigation.

\subsection{COUP-TFs}

The chicken ovalbumin upstream promoter transcription factors, COUP-TFI (NR2F1; also called COUP-TFA, EAR3), COUP-TFII (NR2F2; also called COUP-TFB, ARP-1) and EAR2 (NR2F6, also called ERBAL2), belong to the highly conserved orphan NR subfamily $N R 2 F$. Compared with COUP-TFII, COUP-TFI and EAR2 are less studied in cancer. Extensive studies show that COUP-TFII plays a key role in certain vital processes including development and organogenesis, vasculature and lympangiogenesis, reproduction, and energy metabolism. Aberrant expression of COUP-TFII is observed in some cancers, including pancreatic, breast, colon, ovarian and prostate (39). Studies of transgenic knockout and cancer mouse models show that ablation of COUP-TFII can impair tumor angiogenesis and lymph node metastasis, implicating the involvement of COUP-TFII in regulation of tumor growth and metastasis (40-42). In a NR expression profiling study by quantitative RT-PCR in NCI60 cancer cell panel, it showed that all transcripts of COUP-TFs were expressed at moderate to high levels in prostate cancer cell lines (43). However, the protein level of COUP-TFII was reported to be weakly or undetectable in several prostate cancer cell lines compared with an immortalized non-malignant prostatic epithelial cell line (RWPE-1) in another study (44). The results of expression signatures shown in large number of prostate cancer clinical samples would provide more comprehensive information. ONCOMINE (a cancer microarray database) dataset analysis reveals that COUP-TFII expression is positively correlated with prostate cancer and further increased in metastatic prostate cancers (45). In a genome-wide association study (GWAS), single nucleotide polymorphism (SNP) near the $N R 2 F$ gene/at $N R 2 F 2$ locus was identified to be significantly associated with the circulating levels of sex hormone binding protein (SHBP), a serum protein responsible for vascular transport of sex hormones (46). However, it is unclear whether this kind of SNP association is 
involved in prostate cancer. Immunohistochemistry of COUP-TFII in a prostate tumor tissue microarray study shows that COUP-TFII is significantly upregulated in prostate cancer lesions, and its expression is positively associated with several pathological predictors of aggressiveness and recurrence of prostate cancer (47). Functional studies on COUP-TFII knockout and overexpression transgenic mice reveal that COUP-TFII promotes PTEN-null mediated prostate tumorigenesis through the inhibition of TGF- $\beta$ signaling (47). Since COUP-TFII activity can be modulated by small molecules, targeting of COUP-TFII has been suggested as a potential therapeutic strategy for prostate cancer.

EAR2 represents a critical anti-inflammatory gatekeeper functionally through its negative regulation of the pro-inflammatory Th17 cells and exerts an important regulatory roles in adaptive immunity (48). The correlation of EAR2 expression and human cancers has been observed that EAR2 is significantly upregulated in breast, ovarian, colon cancer and lymphoma. Although the expression of EAR2 in clinical prostate lesions is unknown, a recent study in transgenic TRAMP prostate cancer model shows that genetic ablation of EAR2 $\left(\mathrm{Nr} 2 \mathrm{ft}^{-/- \text {TRAMP }}\right)$ significantly prolongs the survival of TRAMP mice and accompanied with superior immune cell composition. These findings are validated in transplantable $\mathrm{Nr} 2 \mathrm{fb}^{-/-}$ tumor models, in which long lasting host-protective immunological memory against tumor re-challenge is developed. Mechanistic dissection suggests that EAR2 transcriptionally suppresses NFAT/AF-1 complex by directly binding to the promoters of key cytokine genes in $\mathrm{CD}^{+}$and $\mathrm{CD}^{+}$effector $\mathrm{T}$ cells, which are relevant for cancer rejection, thereby acting as a central checkpoint for cancer immune surveillance (49). It waits to demonstrate whether manipulation of the immune system via EAR2 would be a potential strategy for the immunotherapy of prostate cancer. 


\subsection{ERRs}

Estrogen-related receptors or estrogen receptor-related receptors (ERRs, $N R 3 B$ ) were the first orphan NRs identified in 1988 in a search for new members of NRs by a strategy of screening human fetal kidney and adult heart cDNA libraries with a probe containing the DBD of ER $\alpha$ (50). ERRs consist of three closely related subtypes (ERR $\alpha / N R 3 B 1$, ERR $\beta / N R 3 B 2, E R R \gamma / N R 3 B 3)$, which are encoded by three independent genes. The $N R 3 B$ subgroup belongs to the NR3 subfamily, which also contains other classical hormone NRs, such as AR and ER. Although all three ERRs share significant homology with ERs, they do not bind to estrogens or any other physiological ligands and are constitutively active. However, the transcriptional cross-talk between ERRs and steroid hormones signaling has been observed. Actually, ERRs bind to estrogen-response elements (EREs) containing the recognition motif AGGTCA as dimers (51). Promoters containing steroid response element (StRE, ARE, GRE or MMTV) can also be activated by all members of ERRs, although no direct binding of ERRs to StRE is found in vivo (52). Moreover, ERRs can bind to DNA as monomers, which preferentially recognize ERE-related response elements encompassing an extended half-site sequence TnAAGGTCA referred to as the ERR-response element (ERRE). Thus, ERRs can cross-talk with ERs in estrogen signaling via co-targeting to ER-dependent genes and also exert their distinct biological functions and signaling pathways via regulating their own targets. Among the various physiological roles revealed, ERR $\alpha$ and ERR $\gamma$ are characterized as the key transcriptional regulators of energy homeostasis, including glucose metabolism, mitochondrial oxidative metabolism and biogenesis (53). Compared to ERR $\beta$, ERR $\alpha$ and ERR $\gamma$ are widely expressed in many adult tissues, with particularly high levels in organs and tissues of the central nervous, gastrointestinal and cardiovascular systems, which display high metabolic needs. 
Given the important functions of ERRs in energy metabolism in normal tissues, it is not surprising to understand the pivotal role of ERRs in cancer growth regulation by reprogramming metabolic profiles, which is now recognized as a hallmark of cancer (54). ERRs regulate cancer cell growth and tumor progression by manipulating expression of genes involved in aerobic glycolysis that provide energy for rapid growth and proliferation of cancer cells, genes responsible for glucose and glutamine uptake for using of alternative source of energy, and also gene networks in lipid synthesis which is required for cell mass building during the rapid division/proliferation of cancer cells (55). Multiple functional analyses indicate that ERRs favor to cooperate with certain oncogenes or oncogenic signals to modulate some key metabolic regulators (e.g. AMPK) through regulating a set of overlapping targets (e.g. glycolytic enzymes), and via this crosstalk it would augment their respective roles to facilitate metabolic processes that favor tumor growth (Figure 3A). In breast and prostate cancer cells, ERR $\alpha$ is found to physically interact with HIF proteins and with this unique connection, it synergically regulate some key metabolic regulators including genes that encode glucose transporters (such as GLUT1/SCL2A1) and glycolytic enzymes (such as $L D H$ ), and PDK1 gene that blocks TCA cycle and OXPHOS in cancer cells $(56,57)$.

Prostate cancer is metabolically distinct from other solid cancer types, as the cancer cells in other cancers prefer aerobic glycolysis for metabolic reprogramming (58). The nonmalignant prostate epithelial cells exhibit truncated status of TCA cycle due to their high content of intramitochondrial zinc, which drops significantly and leads to an increase of citrate oxidation and oxidative phosphorylation in prostate cancer cells (59). Therefore, aerobic glycolysis may have a less significant impact in prostate cancer, as the increase in glycolysis is only observed in more advanced disease. However, enhanced de novo fatty acid and cholesterol synthesis and increased protein synthesis are commonly shown in both primary and advanced prostate cancer, and their enhanced metabolic activities are positively correlated with the tumor progression and poorer prognosis. Recently, some key molecular 
drivers of metabolic reprogramming have been identified in prostate cancer. The master metabolic regulator 5'-AMP-activated protein kinase (AMPK) is regarded as a pivotal metabolic switch that governs the glucose and lipid metabolism in localized and also metastatic prostate cancer. The PGC- $1 \alpha / \mathrm{ERR} \alpha$ signaling axis has been described as the critical downstream mediator of AMPK metabolic reprogramming in cancer cells (60). Androgens can promote both glycolysis and OXPHOS status in prostate cancer cells through activation of AMPK-PGC-1 $\alpha$ signaling to promote the mitochondrial biogenesis and cell growth (61). Thus, it has the reason to speculate that the ERR $\alpha / \mathrm{PGC}-1 \alpha$ signaling axis may be potentially involved in the AMPK-mediated glucose and lipid metabolism in prostate cancer. Increased protein synthesis can be induced by the PTEN/PI3K/Akt/mTOR pathway, deregulation of which is often detected in most clinical prostate cancer. Although no direct evidence of correlation is shown between the PTEN loss and ERR $\alpha$ activation in prostate cancer cells, liver-specific deletion of PTEN in hepatocytes can induce increased mitochondrial respiration and enhanced glycolysis (similar to the Warburg effect), which is accompanied with upregulation of ERR $\alpha$ (62), This negative correlation between expressions of ERR $\alpha$ and PTEN is also observed in human liver cancer. Moreover, the ERR $\alpha$ induction in Pten-null hepatocytes can promote the transformation and growth potential of these cells (62). It is speculated that such a negative correlation between ERR $\alpha$ and PTEN signaling may also occur in the energy reprogramming in prostate cancer, as PTEN protein is reduced or absent in two-thirds of the clinical tumors.

$E R R \alpha$ was highly expressed in multiple human cancers and play an oncogenic role to promote cancer cell growth (63). Significant high expression levels of ERR $\alpha$ mRNA and protein are detected in multiple prostate cancer cell lines and human prostatic cancer lesions (64). In an expression study on a total of 106 surgically obtained prostate specimens, ERR $\alpha$ expression is highly expressed in cancerous tissues as compared to benign hyperplastic foci, and its elevated expression was significantly correlated with Gleason score and poor cancer-specific survival 
in patients with prostate cancer (65). Much attention has been paid to the role of ERR $\alpha$ in breast cancer due to its close relationship with ERs. Functional analyses performed on cancer cells suggest that ERR $\alpha$ can play regulatory roles in cancer growth through different mechanisms, including modulation of estrogen synthesis (66), cross-talks with pathways mediated by other hormone receptors (ER $\alpha, A R$ and GR) $(52,64,67,68)$, enhancement of HIF-1 signaling (56), promotion of tumor aggressiveness by decreases the stability and activity of the RHOA protein (69) and tumor angiogenesis by targeting to VEGF gene (70-72) and induction of endothelial nitric oxide synthase (eNOS) expression (73), activation of oncogene ERBB2 or HER2 signaling (68) and mediation of oncogenic Ras-dependent anchorage-independent growth (74). However, the functional role of ERR $\alpha$ in prostate cancer is still far from clear. Recently, ERR $\alpha$ has been characterized to play a crucial role in the promotion of HIF-1-dependent hypoxic growth of prostate cancer cells via its direct interaction with the HIF-1 $\alpha$ and prevention of its ubiquitination and degradation (57) (Figure 3B). These results demonstrated that association of ERR $\alpha$ and HIF-1 $\alpha$ can synergistically activates gene networks to support the sustained growth of prostate cancer by metabolism reprogramming and new vasculature formation.

On the contrary, ERR $\beta$ and ERR $\gamma$ display distinct down-regulated expression patterns in advanced prostate cancer as shown in two independent studies $(64,75)$. Clinicopathological analyses reveal that low ERR $\gamma$ expression is associated with poor survival rates in prostate cancer patients. Combined evaluation of the expressions of ERR $\alpha$ and ERR $\gamma$ also show that patients with high ERR $\alpha$ and low ERR $\gamma$ immunoreactivity scores present a poorer cancerspecific survival as compared to patients with low ERR $\alpha$ high ERR $\gamma$ scores, suggesting the combination analysis of ERR $\alpha$ and ERR $\gamma$ could be useful prognostic markers for prostate cancer (75). Functional analyses indicated that both ERR $\beta$ and ERR $\gamma$ exert anti-proliferative and tumor suppressive functions in prostate cancer cells through their direct transactivation of two cell cycle-dependent kinase inhibitors $\mathrm{p} 21^{\mathrm{WAF} 1 / \mathrm{CIP} 1}$ and $\mathrm{p} 27^{\mathrm{KIP} 1}(76,77)$. 


\subsection{NGFI-Bs}

Members of the nerve growth factor-induced B (NGFI-B, NR4A) subfamily (the nomenclature in this subgroup is very confusing due to multiple names given to orthologous versions of the same gene) contains three members in vertebrates including NGFI-B (NR4A1; also named as NAK1, NUR77, ST-59, TR3 or NGFI-B $\alpha$; thereafter named as NGFI-B), NURR1 (NR4A2; also named as NOT, TINUR or NGFI-B $\beta$ ) and NOR1 (NR4A3; also named TEC, MINOR, CHN, or NGFI-B $\gamma)$. NGFI-B receptors are shown to regulate multiple physiological processes and are involved in diseases, including cancer (recent reviews refer to references $(7,78-80)$.

NGFI-Bs play dual and opposite roles in the regulation of cell survival and apoptosis via different mechanisms and pathways depending on specific cellular context $(79,81)$. The proapoptotic and anti-apoptotic roles of NGFI-B, as well as the pathways involved in apoptosis triggered by its inactivation, are summarized in the Figure 4. Small-molecule agonists or antagonists of NGFI-Bs, which can modulate their transcription functions, can be the potential anti-cancer drugs $(79,80)$. Methylene-substituted diindolylmethane (DIM) compounds are identified as agonists or antagonists of NGFI-B, and inhibit in vitro and in vivo growth of multiple cancer cells. Molecular analyses reveal that C-DIM analog DIM-C$\mathrm{pPhOCH}_{3}$ can decrease pancreatic cancer cell survival and induce cell growth arrest either through NGFI-B-dependent induction of p21 (82) or induction of some pro-apoptotic regulatory proteins FasL and TRAIL (83), independent of NGFI-B's translocation to mitochondria. Intriguingly, some selected compounds in the series of DIM analogs, such as DIM-C-pPhO, DIM-C-pPhOH and DIM-C-pPhCO ${ }_{2} \mathrm{Me}$, act as NGFI-B antagonists. These compounds can induce apoptosis and inhibit tumor growth of cancers, such as pancreatic (84), lung (85), colon (86), breast cancer cells (81) and renal cell adenocarcinoma (87), where NGFI-B is overexpressed, via targeting and suppression of NGFI-B-mediated pro-oncogenic 
pathways. NGFI-B is shown to promote breast cancer invasion and metastasis by activating TGF- $\beta$ /SMAD signaling (88) and NGFI-B antagonists can significantly suppress TGF- $\beta$ induced migration of breast cancer cells (89). Cytosporone B (Csn-B), an octaketide antibiotic isolated from an endophytic fungus, and its analogues were identified a new class of anti-tumor agents (90-92). Recently, a chemical compound THPN [1-(3,4,5trihydroxyphenyl)nonan-1-one] was confirmed as a new NGFI-B-specific agonist, which can effectively mediate autophagic cell death and mitochondrial targeting in melanoma cells and inhibit melanoma growth (93).

Previous reports suggested that NGFI-B plays a role in regulation of apoptosis in prostate cancer cells. The expression of NGFI-B is androgen-sensitive in LNCaP prostate cancer cells and its expression can be induced rapidly in apoptotic prostate cancer cells mediated by calcium ionophore (94). Knockdown of NGFI-B by antisense oligonucleotide can confer resistance to calcium ionophore-induced apoptosis in prostate cancer cells (94). In prostate cancer cells, NGFI-B can mediate apoptosis via direct transactivation of E2F1 transcription factor (95), direct interaction with anti-apoptotic protein $\mathrm{Bcl}-\mathrm{B}$ in mitochondria (96), and nucleus-mitochondria translocation (97). Moreover, overexpression of NGFI-B can enhance chemo-sensitivity of docetaxel in chemo-resistant prostate cancer sublines PC-3R (98). Since NGFI-B expression can be induced by some pro-apoptotic agents, like calcium ionophore/etoposide (94), PKC-inducer TPA (95) and analogs of gonadotropin-releasing hormone (GnRH) (99) in prostate cancer cells, NGFI-B could be a potential drug target for this cancer. Aberrant expression of NURR1 is reported in a variety of cancers, including breast, bladder, stomach and colon cancers. In a recent study, it was shown that NURR1 exhibited increased immunoexpression in prostate cancer and its expression level appears to be positively correlated with tumor stage and Gleason score, and its transient knockdown by siRNA could induce apoptosis and inhibit in vitro cell proliferation and migration of PC-3 
prostate cancer cells (100). The specific role of NGFI-B family in apoptosis regulation deserves further investigation as targeting apoptosis is a main strategy in anti-cancer therapy.

\subsection{LRH-1}

Liver receptor homolog-1 (LRH-1, NR5A2; also called FTF, CPF, hBIF, FTZ-F1 $\beta$ ) is named as it was originally cloned from a mouse liver cDNA library and identified as a transcription factor that bind to DNA response elements in promoters of some liver-specific genes involved in metabolism. Transgenic mouse and clinical studies indicate that dysregulation of intestinal LRH-1 expression and LRH-1-regulated steroidogenesis contributes to the development of colon carcinomas $(101,102)$, while knockdown of LRH-1 in colorectal cancer cells significantly impair their proliferation (103). Increased LRH-1 expression is also detected in multiple cancers, including breast (104), gastric (105), pancreatic (106) and ovarian epithelial and granulosa cell tumors (107). In vitro studies shows that LRH-1 can promote breast cancer cell proliferation and migration in an ER $\alpha$ dependent or -independent manner (108). In silico analysis predicts that LRH-1 binding sites are found in several genes encoding enzymes involved in glycolysis, gluconeogenesis, pentose phosphate pathway, fatty acid biosynthesis and metabolism, suggesting that LRH-1 may directly regulate these metabolic processes (109). Recent studies in stem cells also showed that LRH-1 could function to regulate the maintenance and pluripotency of stem cells via its interaction with some core stem cell-regulatory Yamanaka transcription factors (Oct3/4, Sox2, Klf4 and c-Myc) $(110,111)$. Although LRH-1 is considered as a constitutively active orphan NR, a few studies show that some phospholipids can bind to its LBD and help to recruit coactivators $(112,113)$ and also the dietary phospholipid dilauroyl phosphatdylcholine can activate LRH-1 in mouse (114). Moreover, some synthetic nonphospholipid small molecules have been shown to act as in verse agonists or antagonists of LRH-1 (115-117). 
Our recent study and unpublished data showed that LRH-1 might contribute to the CRPC progression by promoting de novo intratumoral androgen synthesis through its positive regulation on the expression of several critical enzymes in steroidogenesis, including CYP17A1, HSD3B1, HSD3B2 and steroidogenic acute regulatory protein (StAR) (118). Transcriptional regulation of LRH-1 in steroidogenesis has been well-characterized in gonads and adipose tissue, where it induces gene transcription of steroidogenic enzymes, including StAR, P450scc, P450c17, 3ßHSD2, CYP11B1, CYP11B2, and aromatase. Significant association between LRH-1 and P450scc or StAR immunoreactivity is also observed in breast carcinoma tissues (104). Based on the current understanding of molecular mechanisms underlying CRPC progression, one hypothesis has attracted much attention: local (intraprostatic or intratumoral) synthesis of androgen by prostatic cells via increased expression of steroidogenic enzymes (e.g. CYP17) may contribute to AR transactivation and CRPC growth, and therefore the crucial enzymes in androgen synthesis can be the potential therapeutic targets for CRPC. Our study showed that overexpression of LRH-1 in androgendependent prostate cancer cells could promote in vitro androgen-independent growth and in vivo castration-resistant growth, and this growth promotion effect could be restored by the CYP17A1 inhibitor abiraterone. Moreover, high levels of intratumoral androgens (testosterone and dihydrotestosterone) were detected in LRH-1 overexpressed xenograft tumors. The working model of LRH-1 in de novo androgen synthesis in prostate cancer cells is illustrated in Figure 5.

\subsection{GCNF}

Mammalian germ cell nuclear factor (GCNF, NR6Al) was first isolated from a mouse heart cDNA library by screening with a fragment of orphan receptor PPAR $\beta(N R 1 C 2)$ and expressed in the developing germ cells (119). Human GCNF homolog was subsequently isolated from testis or neuronal precursor cell cDNA libraries by screening with mouse GCNF (120). It is the only member in the NR6 subfamily. Functional analyses and knockout 
mice studies suggested that GCNF functions as a transcriptional repressor and plays regulatory roles in embryogenesis, neurogenesis and gametogenesis (121). GCNF is required for the Oct 4 expression restricted to primordial germ cells after gastrulation. However, its role in malignancy is still unclear. One previous DNA microarray study showed that GCNF is highly expressed in seminomas and is suggested to be involved in the determination of their pluripotent nature (122). In a recent study on the expression of testis-related cancer genes in prostate cancer tissues, GCNF expression is observed to be significantly associated with prostate cancer progression and aggressiveness, as its mRNA and protein expression is significantly up-regulated in hormone-sensitive cancer and further elevated in castrationresistant and metastatic prostate cancer, and GCNF expression is positively related with Gleason score (123).

\subsection{DAX1}

DAX1 (dosage-sensitive sex reversal/DSS-adrenal hypoplasia congenital/AHC critical region on $\mathrm{x}$ chromosome, gene $1 ; N R O B 1$ ) is an unusual member of orphan $\mathrm{NR}$, as it contains a conserved LBD but lacks the canonical zinc finger-containing DBD. Its N-terminus contains three repeats of LXXLL motifs, which mediate the subcellular distribution and nuclear localization of DAX1 (124). DAX1 is originally shown to function primarily as a transcriptional repressor and suppress the transcriptional activities of multiple transcription factors and hormone NRs, including ERs, PR and AR (125). Besides, the transcriptional activities of many orphan NRs, including SF1 (NR5A1), LRH-1 (NR5A2), NGFI-B (NR4A1), SHP (NROB2), ERR $\gamma(N R 3 B 3)$ and HNF4 $\alpha$ (NR2A1), can also be suppressed by DAX1 (126). Instead of directly binding to regulatory DNA sites likely due to absence of DBD, DAX1 mediates the transcriptional repression of NRs through a unique mechanism of proteinprotein interaction between DAX1 and DNA-bound NRs. DAX1 can bind to the AF-2 domain of the NRs via its N-terminal LXXLL motifs, thereafter directly occupies the coactivator-binding surface and subsequently recruits corepressors to the promoters of target 
genes. Other mechanisms of DAX1-mediated repression include interfering with the functional dimerization of NRs, preventing the nuclear translocation of ligand-activated NRs, as well as binding to hairpin elements in the promoters of target genes (126).

The expression of DAX1 in Ewing's sarcoma and cancers of the breast, ovary, endometrium, lung and prostate has been described, though its expression pattern in cancer progression is discrepant amongst different types of cancers. A higher expression level of DAX1 was found to be correlated with higher rates of lymph node metastasis in lung adenocarcinoma. Knockdown of DAX1 can significantly inhibit the invasion capability of lung cancer cells (127). DAX1 is induced by the oncoprotein chimerical transcription factors (EWS/FLI1) and highly expressed in Ewing's tumors and play an important role in cell-cycle progression $(128,129)$. However, the tumor-promoting function of DAX1 appears to be context dependent. DAX1 depletion can induce cancer cell migration and metastasis potential in hepatocellular carcinoma where the expression level of DAX1 is down-regulated (130).

DAX1 is predominantly expressed in both mammalian male and female reproductive organs (including testis, prostate and ovary) and the adrenal gland, in which it plays regulatory roles in steroidogenesis, development and reproductive functions in these organs via its interplay with different NRs (125). The expression pattern of DAX1 in normal prostate and prostate cancer is controversial. It is observed that strong nuclear immunoreactivity of DAX1 is shown in the normal prostatic epithelial cells but reduced in benign prostatic hyperplasia $(\mathrm{BPH})(125,131)$. Besides, RT-PCR analysis also demonstrates that DAX1 transcripts are detected in the PrEC primary cultured prostatic epithelial cells but not in PC-3 prostate cancer cells (132). However, in another immunohistochemical study in prostate cancer tissues, it is reported that DAX1 exhibited a variable expression pattern in the nuclei of prostate cancer cells and its immunoreactivity displayed an inverse correlation with Gleason score, whereas it shows negative immunoreactivity in normal prostate (133). Its expression can also be suppressed by miR-181, a miRNA that can promote the prostate 
cancer cell proliferation (134). The exact function of DAX1 in normal prostate and prostate cancer development is still unclear and further investigations are needed.

\subsection{SHP}

Short heterodimer partner (SHP, NROB2) is another unusual orphan NR, without the classical DBD/which lacks the classical DBD, like its closest relative DAX1 (135). As indicated by its name, SHP predominantly functions as a transcriptional repressor of gene expression and suppressor of signalings mediated by some NRs, including AR, ERs, ERRs, LRH-1 and DAX1, through its direct binding to these target NRs. Three distinct molecular mechanisms involved in SHP-mediated repression of target genes of NRs have been characterized: competition for coactivator binding to NR, recruitment of SHP-associated corepressors, and inhibition of DNA binding (136). Information on the expression and role of SHP in prostate cancer is limited so far. A recent study shows that SHP exhibits a downregulation pattern in several human prostate cancer cell lines as compared to non-malignant immortalized prostatic epithelial cells, and its down-regulation as specifically targeted by miR-141 can promote the AR transcriptional activity in prostate cancer cells (137). Some synthetic SHP ligands can induce apoptosis and suppress the in vitro growth of DU145 prostate cancer cells (138), suggesting SHP may perform a growth inhibitory function in prostate cancer cells.

\section{Interaction of orphan NRs with AR signaling pathway}

It is well characterized that androgen receptor ( $\mathrm{AR}, N R 3 C 4)$ plays critical roles in normal prostate development and also prostate cancer progression. In CRPC, most cancer cells maintain activated AR signaling and hormone sensitivity despite low levels of serum testosterone. Current findings suggest that multiple molecular mechanisms are involved in the progression of CRPC, including (1) AR hypersensitivity due to AR gene amplification and overexpression, AR mutations and expression of AR splice variants; (2) alternations on co- 
regulators; (3) intracellular or intratumoral androgen synthesis by cancer cells; (4) activation of ligand-independent and AR-dependent pathways by increased transduction signalings (e.g. PTEN/PI3K/Akt) activated by oncogenic growth factors and cytokines via tyrosine kinase receptors; (5) eNOS pathway; (6) AR-independent pathways (e.g. antiapoptotic AR-bypass pathway, cancer stem cell pathway) $(139,140)$. Besides these mechanisms, evidences also show that decreased AR expression or its activity can also contribute to the progression of CRPC. A genome-wide microarray expression study of large-scale prostate cancer samples identifies that androgen signaling is decreased in metastatic and high Gleason-score prostate cancer compared with localized and low Gleason-score cancers (45). Elevated expression of an AR-repressing transcription factor E2F1 may contribute to the decreased AR expression as detected in metastatic lymph nodes from hormone-naïve patients and metastatic CRPC (141). The dysregulated AR signaling and multiple molecular pathways as utilized by the prostate cancer cells also suggest the heterogeneity of tumor cells in CRPC (141-143).

Interestingly, some orphan nuclear receptors, including retinoic acid-related orphan receptor $\gamma(\mathrm{ROR} \gamma, N R 1 F 3)$, TR2, TR4, COUP-TFII, ERR $\alpha, \mathrm{DAX} 1$ and SHP, have been shown to interfere with the AR signaling pathway via different mechanisms, suggesting that these orphan NRs may contribute to the normal and malignant development of prostate via their interference and cross-talk with AR signaling. One latest study reveals that AR expression is driven by the upregulation of ROR $\gamma$ in metastatic CRPC (144). ROR $\gamma$ can controls $A R$ gene expression through its direct binding to AR promoter via exonic RORbinding element and association with steroid receptor coactivator members (SRCs). ROR $\gamma$ specific agonist can potently inhibit prostatic tumor growth and metastasis in vivo (144). Androgen exercises opposite roles on TR2 and TR4: represses TR2 (14) and induces TR4 expression (145). However, both TR2 and TR4 are shown to interfere with AR action by its interaction with AR and suppress AR-mediated transactivation $(15,146)$. Interestingly, TR4 and AR form a heterodimer that represses the expression of both TR4 and AR target genes 
(146). COUP-TFII physically interacts with the DBD and LBD of AR and represses AR transactivation by inhibiting AR recruitment to its targets and also by competing with AR coactivators (44). For ERR $\alpha$, it can not only interfere with the estrogen-signaling pathway $(66,147)$, but also cross-talk with androgen signaling as androgen-responsive genes (such as PSA) can be down-regulated by ERR $\alpha$-specific inverse agonist XCT790 in androgen responsive prostate cancer cells without influence AR expression or activity (52). Even in the presence of antiandrogen, ERR $\alpha$ still stimulates the activity of androgen-responsive element (ARE)-containing promoters, which indicates that the ERR $\alpha$ overexpression in prostate cancer may play a role in antiandrogen-resistance (52). DAX1, an AR target gene which is induced by the ligand-activated $\mathrm{AR}$ in breast cancer cells (148), can repress the transcriptional activity of AR and modulate androgen-dependent gene transcription in target cells $(131,149)$. A mechanistic study reveals that DAX1 interferes with the dimerization and inter-domain communication of the AR and prevents its translocation into the nucleus (131). SHP is also characterized as a direct repressor of AR. Despite significant sequence similarity shown in the putative LBD of SHP and DAX1, the mechanism of SHP-mediated repression on AR differs from that of DAX1. SHP can inhibit the transcriptional activity of AR by competing with the AR coactivators or recruiting of histone deacetylase 1 (HDAC1) (150152).The actions and mechanisms of orphan nuclear receptors on AR is summarized in Figure 6.

\section{Remarks and perspectives}

Among the NR superfamily, AR has been extensively studied and represents the most established therapeutic target in prostate cancer. However, almost all patients receiving hormone therapies targeting to AR-axis signaling still inevitably develop therapy resistance. Therefore, targeting alternative signaling pathways may provide potential opportunities to prostate cancer treatment, especially its advanced metastatic castration-resistant disease. Over 
the years, studies on orphan NRs have gained significant advances on our current understanding on their important roles in cancer. Regarding prostate cancer, some of the orphan NRs are characterized to play roles in cell proliferation via their independent transcriptional control of gene networks and or cross-talk with AR signaling, as summarized in Table 1. However, their specific roles in prostate cancer are only beginning to emerge as the involved mechanisms and pathways are still poorly understood. Some orphan NRs, such as Rev-erb $\alpha / \beta(N R 1 D 1 / 2)$, RORs $(N R 1 F)$, PNR (NR2E3), which were also found to be expressed in prostatic cells (43), has not been well characterized in prostate cancer. Given their important roles in the transcriptional control of growth, energy metabolism, steroidogenesis and other cellular processes, some these orphan NRs could be potential therapeutic targets for better treatment of prostate cancer, particularly the advanced castration-resistant disease. 
Table 1. Orphan NRs in prostate cancer

\begin{tabular}{|c|c|c|c|c|c|}
\hline $\begin{array}{l}\text { Gene } \\
\text { names }\end{array}$ & $\begin{array}{c}\text { Common } \\
\text { names }\end{array}$ & $\begin{array}{c}\text { Selected } \\
\text { molecules }\end{array}$ & Expression patterns in prostate cancer & $\begin{array}{c}\text { Characterized functions in prostate and } \\
\text { prostate cancer }\end{array}$ & $\begin{array}{c}\text { Reference } \\
\text { s }\end{array}$ \\
\hline NR1F3 & RORy & $\begin{array}{l}\text { SR2211; } \\
\text { XY018; } \\
\text { XY011 }\end{array}$ & $\begin{array}{l}\text { Significantly upregulated in metastatic } \\
\text { prostate cancer }\end{array}$ & Promotes AR expression. & $(144)$ \\
\hline$N R 2 C 1$ & TR2 & Unknown & Not characterized & $\begin{array}{l}\text { 1. Suppresses AR-mediated transactivation; } \\
\text { 2. Expression of TR2 can be suppressed by } \\
\text { androgen }\end{array}$ & $(14,15)$ \\
\hline$N R 2 C 2$ & TR4 & $\begin{array}{l}\text { Retinol; } \\
\text { retinoic acid }\end{array}$ & $\begin{array}{l}\text { 1. Positively correlated with Gleason score; } \\
\text { 2. Highly expressed in prostate cancer } \\
\mathrm{CD}_{133^{+}} \text {stem/progenitor cells compared } \\
\text { with } \mathrm{CD}_{133^{-} \text {cells; }} \\
\text { 3. Highly expressed in biochemical } \\
\text { recurrence patients after brachytherapy. }\end{array}$ & $\begin{array}{l}\text { 1. Suppresses AR-mediated transactivation; } \\
\text { 2. Regulate chemoresistance of prostate } \\
\text { cancer } \mathrm{CD} 133^{+} \text {stem/progenitor cells; } \\
\text { 3. Promotes prostate cancer metastasis via } \\
\text { upregulation of } \mathrm{CCL} 2 / \mathrm{CCR} 2 \text {; } \\
\text { 4. Enhance radio-resistance. }\end{array}$ & $\begin{array}{l}(19-21 \\
146,153)\end{array}$ \\
\hline$N R 2 E 1$ & TLX & $\begin{array}{l}\text { Famprofazone; } \\
\text { 1-(1,5- } \\
\text { dimethylpyrazole } \\
\text {-3-carbonyl)-4- } \\
\text { (diphenylmethyl) } \\
\text { piperazine; } \\
\text { Dydrogesterone }\end{array}$ & Positively correlated with Gleason score & $\begin{array}{l}\text { 1. Promotes prostate cancer cell growth and } \\
\text { migration } \\
\text { 2. Suppresses premature senescence by trans- } \\
\text { regulation on } C D K N 1 A \text { and SIRT1 genes. }\end{array}$ & $(32,154)$ \\
\hline$N R 2 F 2$ & COUP-TFII & Retinoid acids & $\begin{array}{l}\text { 1. Highly expressed in tumor cells and } \\
\text { significantly associated with cancer } \\
\text { aggressiveness; } \\
\text { 2. Serve as a predictor to stratify risk of } \\
\text { recurrence in patients; }\end{array}$ & $\begin{array}{l}\text { 1. Represses AR transactivation as an AR } \\
\text { corepressor; } \\
\text { 2. Cooperates with PTEN deletion to promote } \\
\text { prostate carcinogenesis and metastatic } \\
\text { potential via suppression of TGF- } \beta \text { - } \\
\text { dependent growth barrier. }\end{array}$ & $\begin{array}{l}(44,47 \\
155)\end{array}$ \\
\hline NR2F6 & EAR2 & Unknown & Not characterized & $\begin{array}{l}\text { Control the effector } \mathrm{T} \text { cell-dependent anti- } \\
\text { tumor immunity by repression of key cytokines } \\
\text { in } \mathrm{CD} 4^{+} \text {and } \mathrm{CD} 8^{+} \text {effector } T \text { cells. }\end{array}$ & (49) \\
\hline
\end{tabular}




\begin{tabular}{|c|c|c|c|c|c|}
\hline NR3B1 & $\mathrm{ERR} \alpha$ & $\begin{array}{l}\text { XCT790; } \\
\text { SR16388 }\end{array}$ & $\begin{array}{l}\text { 1. Heterogeneously expressed in low } \\
\text { Gleason grade cancer; } \\
\text { 2. Significantly higher in tumor than in } \\
\text { benign foci } \\
\text { 3. Positively correlated with the Gleason } \\
\text { score; }\end{array}$ & $\begin{array}{l}\text { 1. Cross-talk with androgen signaling pathways } \\
\text { by regulate androgen-responsive genes; } \\
\text { 2. Contributes to local estrogen production by } \\
\text { up-regulating aromatase expression in } \\
\text { response to PGE2 in prostate stromal cells; } \\
\text { 3. Promotes hypoxic adaptation via interaction } \\
\text { with HIF-1 } \alpha \text { to inhibit HIF-1 } \alpha \text { ubiquitination }\end{array}$ & $\begin{array}{l}(52,57 \\
64,65 \\
147)\end{array}$ \\
\hline NR3B2 & ERR $\beta$ & $\begin{array}{l}\text { Diethylstilbestrol } \\
\text { 4-OHT } \\
\text { GSK5182 } \\
\text { DY131 }\end{array}$ & Down-regulated in cancer lesions & $\begin{array}{l}\text { Inhibits cancer cell growth via direct control of } \\
\text { cell-cycle regulators } \mathrm{p} 21 \text { and } \mathrm{p} 27 \text {. }\end{array}$ & $\begin{array}{l}(64,75 \\
77)\end{array}$ \\
\hline NR3B3 & ERRY & $\begin{array}{l}\text { Diethylstilbestrol } \\
\text { 4-OHT } \\
\text { GSK5182 } \\
\text { DY131 }\end{array}$ & $\begin{array}{l}\text { 1. Down-regulated in prostate cancer cell } \\
\text { lines and prostate cancer tissues; } \\
\text { 2. Correlated with poorer cancer-specific } \\
\text { survival. }\end{array}$ & $\begin{array}{l}\text { Inhibits cancer cell proliferation via direct control } \\
\text { of cell-cycle regulators p } 21 \text { and p } 27 \text {. }\end{array}$ & $\begin{array}{l}(64,75 \\
76)\end{array}$ \\
\hline NR4A1 & NGFI-B & $\begin{array}{l}\text { Csn-B; } \\
\text { THPN; } \\
\text { C-DIM analogs }\end{array}$ & Not characterized & $\begin{array}{l}\text { 1. Regulates cancer cell apoptosis by } \\
\text { interacting with IGFBP-3; } \\
\text { 2. Mediated docetaxel chemoresistantce }\end{array}$ & $\begin{array}{l}(94,95 \\
97,98)\end{array}$ \\
\hline NR4A2 & NURR1 & $\begin{array}{l}\text { Benzimidazoles } \\
\text { DIM-C-pPhCl }\end{array}$ & $\begin{array}{l}\text { Higher in prostate cancer tissues than in } \\
\text { benign prostate tissue. }\end{array}$ & $\begin{array}{l}\text { Promotes cancer cell proliferation, migration and } \\
\text { invasion, and inhibits apoptosis }\end{array}$ & $(100)$ \\
\hline NR6A1 & GCNF & Unknown & $\begin{array}{l}\text { 1. Up-Regulated in Castration-Resistant } \\
\text { Prostate Cancers; } \\
\text { 2. Significantly associated with prostate } \\
\text { cancer progression and aggressiveness }\end{array}$ & Not characterized & $(123)$ \\
\hline NROB1 & DAX1 & Thiocolciran & Inversely correlated with Gleason score. & $\begin{array}{l}\text { 1. Represses AR activity; } \\
\text { 2. regulates steroid hormone production } \\
\end{array}$ & $(131,133)$ \\
\hline NROB2 & SHP & $\begin{array}{l}\text { AHPC; } \\
\text { 3-Cl-AHPC }\end{array}$ & Down-regulated in prostate cancer cell lines. & $\begin{array}{l}\text { 1. Interact with AR and represses AR activity; } \\
\text { 2. SHP ligand inhibits prostate cancer cell } \\
\text { growth }\end{array}$ & $\begin{array}{l}(137,138, \\
152)\end{array}$ \\
\hline
\end{tabular}

Nomenclature used is based on the system defined by the NRs nomenclature committee (156). 


\section{Acknowledgements}

This work was supported by the Earmarked Research Grant (CUHK4411/06M), General Research Funds $(461009,14100914)$ from the Research Grants Council of Hong Kong and National Science Foundation of China (81502570). 


\section{References}

1. $\quad$ Siegel RL, Miller KD, Jemal A. Cancer statistics, 2016. CA Cancer J Clin. 2016;66:730.

2. Chen W, Zheng R, Baade PD, Zhang S, Zeng H, Bray F, Jemal A, Yu XQ, He J. Cancer statistics in China, 2015. CA Cancer J Clin. 2016;66:115-32.

3. Gelmann EP. Androgen Receptor Biology in Prostate Cancer. Drug Management of Prostate Cancer. In: Figg WD, Chau CH, Small EJ, editors.: Springer New York; 2010. p. 61-70.

4. Safe S, Kim K. Non-classical genomic estrogen receptor (ER)/specificity protein and ER/activating protein-1 signaling pathways. J Mol Endocrinol. 2008;41:263-75.

5. Benoit G, Cooney A, Giguere V, Ingraham H, Lazar M, Muscat G, Perlmann T, Renaud JP, Schwabe J, Sladek F, Tsai MJ, Laudet V. International Union of Pharmacology. LXVI. Orphan nuclear receptors. Pharmacol Rev. 2006;58:798-836.

6. Baek SH, Kim KI. Emerging roles of orphan nuclear receptors in cancer. Annu Rev Physiol. 2014;76:177-95.

7. Safe S, Jin UH, Hedrick E, Reeder A, Lee SO. Minireview: role of orphan nuclear receptors in cancer and potential as drug targets. Mol Endocrinol. 2014;28:157-72.

8. Roshan-Moniri M, Hsing M, Butler MS, Cherkasov A, Rennie PS. Orphan nuclear receptors as drug targets for the treatment of prostate and breast cancers. Cancer Treat Rev. 2014;40:1137-52.

9. Chang C, Kokontis J. Identification of a new member of the steroid receptor superfamily by cloning and sequence analysis. Biochem Biophys Res Commun. 1988;155:971-7.

10. Chang C, Da Silva SL, Ideta R, Lee Y, Yeh S, Burbach JP. Human and rat TR4 orphan receptors specify a subclass of the steroid receptor superfamily. Proc Natl Acad Sci U S A. 1994;91:6040-4.

11. Chang C, Kokontis J, Acakpo-Satchivi L, Liao S, Takeda H, Chang Y. Molecular cloning of new human TR2 receptors: a class of steroid receptor with multiple ligandbinding domains. Biochem Biophys Res Commun. 1989;165:735-41.

12. Murty VV, Houldsworth J, Baldwin S, Reuter V, Hunziker W, Besmer P, Bosl G, Chaganti RS. Allelic deletions in the long arm of chromosome 12 identify sites of candidate tumor suppressor genes in male germ cell tumors. Proc Natl Acad Sci U S A. 1992;89:11006-10.

13. Hu YC, Shyr CR, Che W, Mu XM, Kim E, Chang C. Suppression of estrogen receptormediated transcription and cell growth by interaction with TR2 orphan receptor. J Biol Chem. 2002;277:33571-9.

14. Ideta R, Yeh S, Lee Y, Adachi K, Takeda H, Su C, Saltzman A, Chang C. Gene expression of the androgen repressed rat TR2 orphan receptor: a member of steroid receptor superfamily. Endocrine. 1995;3:277-83.

15. $\mathrm{Mu} \mathrm{X}$, Chang $\mathrm{C}$. TR2 orphan receptor functions as negative modulator for androgen receptor in prostate cancer cells PC-3. Prostate. 2003;57:129-33.

16. Collins LL, Lee YF, Heinlein CA, Liu NC, Chen YT, Shyr CR, Meshul CK, Uno H, Platt KA, Chang C. Growth retardation and abnormal maternal behavior in mice 
lacking testicular orphan nuclear receptor 4. Proc Natl Acad Sci $U$ S A. 2004;101:15058-63.

17. Lee YF, Liu S, Liu NC, Wang RS, Chen LM, Lin WJ, Ting HJ, Ho HC, Li G, Puzas EJ, Wu Q, Chang C. Premature aging with impaired oxidative stress defense in mice lacking TR4. Am J Physiol Endocrinol Metab. 2011;301:E91-8.

18. Shyr CR, Hu YC, Kim E, Chang C. Modulation of estrogen receptor-mediated transactivation by orphan receptor TR4 in MCF-7 cells. J Biol Chem. 2002;277:146228 .

19. Ding X, Yang DR, Lee SO, Chen YL, Xia L, Lin SJ, Yu S, Niu YJ, Li G, Chang C. TR4 nuclear receptor promotes prostate cancer metastasis via upregulation of CCL2/CCR2 signaling. Int J Cancer. 2015;136:955-64.

20. Yu S, Wang M, Ding X, Xia L, Chen B, Chen Y, Zhang Z, Niu Y, Li G, Chang C. Testicular orphan nuclear receptor 4 is associated with the radio-sensitivity of prostate cancer. Prostate. 2015;75:1632-42.

21. Yang D-R, Ding X-F, Luo J, Shan Y-X, Wang R, Lin S-J, Li G, Huang C-K, Zhu J, Chen Y, Lee SO, Chang C. Increased chemosensitivity via targeting testicular nuclear receptor 4 (TR4)-Oct4-interleukin 1 receptor antagonist (IL1Ra) axis in prostate cancer CD133+ stem/progenitor cells to battle prostate cancer. J Biol Chem. 2013;288:1647683.

22. Yu RT, McKeown M, Evans RM, Umesono K. Relationship between Drosophila gap gene tailless and a vertebrate nuclear receptor Tlx. Nature. 1994;370:375-9.

23. Jackson A, Panayiotidis P, Foroni L. The human homologue of the Drosophila tailless gene (TLX): characterization and mapping to a region of common deletion in human lymphoid leukemia on chromosome 6q21. Genomics. 1998;50:34-43.

24. Shi Y, Chichung Lie D, Taupin P, Nakashima K, Ray J, Yu RT, Gage FH, Evans RM. Expression and function of orphan nuclear receptor TLX in adult neural stem cells. Nature. 2004;427:78-83.

25. Liu HK, Wang Y, Belz T, Bock D, Takacs A, Radlwimmer B, Barbus S, Reifenberger G, Lichter P, Schutz G. The nuclear receptor tailless induces long-term neural stem cell expansion and brain tumor initiation. Genes Dev. 2010;24:683-95.

26. Zou Y, Niu W, Qin S, Downes M, Burns DK, Zhang CL. The nuclear receptor TLX is required for gliomagenesis within the adult neurogenic niche. Mol Cell Biol. 2012;32:4811-20.

27. Chavali PL, Saini RK, Zhai Q, Vizlin-Hodzic D, Venkatabalasubramanian S, Hayashi A, Johansson E, Zeng ZJ, Mohlin S, Pahlman S, Hansford L, Kaplan DR, Funa K. TLX activates MMP-2, promotes self-renewal of tumor spheres in neuroblastoma and correlates with poor patient survival. Cell Death Dis. 2014;5:e1502.

28. Zhu Z, Khan MA, Weiler M, Blaes J, Jestaedt L, Geibert M, Zou P, Gronych J, Bernhardt O, Korshunov A, Bugner V, Lichter P, Radlwimmer B, Heiland S, Bendszus M, Wick W, Liu HK. Targeting self-renewal in high-grade brain tumors leads to loss of brain tumor stem cells and prolonged survival. Cell Stem Cell. 2014;15:185-98.

29. Cui Q, Yang S, Ye P, Tian E, Sun G, Zhou J, Liu X, Chen C, Murai K, Zhao C, Azizian KT, Yang L, Warden C, Wu X, D'Apuzzo M, Brown C, Badie B, Peng L, Riggs AD, Rossi JJ, Shi Y. Downregulation of TLX induces TET3 expression and inhibits glioblastoma stem cell self-renewal and tumorigenesis. Nat Commun. 2016;7:10637. 
30. Zeng ZJ, Johansson E, Hayashi A, Chavali PL, Akrap N, Yoshida T, Kohno K, Izumi H, Funa K. TLX controls angiogenesis through interaction with the von Hippel-Lindau protein. Biol Open. 2012;1:527-35.

31. O'Loghlen A, Martin N, Krusche B, Pemberton H, Alonso MM, Chandler H, Brookes S, Parrinello S, Peters G, Gil J. The nuclear receptor NR2E1/TLX controls senescence. Oncogene. 2015;34:4069-77.

32. Wu D, Yu S, Jia L, Zou C, Xu Z, Xiao L, Wong KB, Ng CF, Chan FL. Orphan nuclear receptor TLX functions as a potent suppressor of oncogene-induced senescence in prostate cancer via its transcriptional co-regulation of the CDKN1A (p21(WAF1) (/) (CIP1) ) and SIRT1 genes. J Pathol. 2015;236:103-15.

33. Chen Z, Trotman LC, Shaffer D, Lin HK, Dotan ZA, Niki M, Koutcher JA, Scher HI, Ludwig T, Gerald W, Cordon-Cardo C, Pandolfi PP. Crucial role of p53-dependent cellular senescence in suppression of Pten-deficient tumorigenesis. Nature. 2005;436:725-30.

34. Ahmad I, Patel R, Singh LB, Nixon C, Seywright M, Barnetson RJ, Brunton VG, Muller WJ, Edwards J, Sansom OJ, Leung HY. HER2 overcomes PTEN (loss)-induced senescence to cause aggressive prostate cancer. Proc Natl Acad Sci U S A. 2011;108:16392-7.

35. Pernicova Z, Slabakova E, Kharaishvili G, Bouchal J, Kral M, Kunicka Z, Machala M, Kozubik A, Soucek K. Androgen depletion induces senescence in prostate cancer cells through down-regulation of Skp2. Neoplasia. 2011;13:526-36.

36. Ewald JA, Desotelle JA, Church DR, Yang B, Huang W, Laurila TA, Jarrard DF. Androgen deprivation induces senescence characteristics in prostate cancer cells in vitro and in vivo. Prostate. 2013;73:337-45.

37. Perez-Mancera PA, Young AR, Narita M. Inside and out: the activities of senescence in cancer. Nat Rev Cancer. 2014;14:547-58.

38. Chen X, Rycaj K, Liu X, Tang DG. New insights into prostate cancer stem cells. Cell Cycle. 2013;12:579-86.

39. Xu M, Qin J, Tsai SY, Tsai MJ. The role of the orphan nuclear receptor COUP-TFII in tumorigenesis. Acta Pharmacol Sin. 2015;36:32-6.

40. Navab R, Gonzalez-Santos JM, Johnston MR, Liu J, Brodt P, Tsao MS, Hu J. Expression of chicken ovalbumin upstream promoter-transcription factor II enhances invasiveness of human lung carcinoma cells. Cancer Res. 2004;64:5097-105.

41. Qin J, Chen X, Xie X, Tsai MJ, Tsai SY. COUP-TFII regulates tumor growth and metastasis by modulating tumor angiogenesis. Proc Natl Acad Sci $U$ S A. 2010;107:3687-92.

42. Nagasaki S, Suzuki T, Miki Y, Akahira J, Shibata H, Ishida T, Ohuchi N, Sasano H. Chicken ovalbumin upstream promoter transcription factor II in human breast carcinoma: possible regulator of lymphangiogenesis via vascular endothelial growth factor-C expression. Cancer Sci. 2009;100:639-45.

43. Holbeck S, Chang J, Best AM, Bookout AL, Mangelsdorf DJ, Martinez ED. Expression profiling of nuclear receptors in the NCI60 cancer cell panel reveals receptor-drug and receptor-gene interactions. Mol Endocrinol. 2010;24:1287-96. 
44. Song $\mathrm{CH}$, Lee HJ, Park E, Lee K. The chicken ovalbumin upstream promotertranscription factor II negatively regulates the transactivation of androgen receptor in prostate cancer cells. PLoS One. 2012;7:e49026.

45. Tomlins SA, Mehra R, Rhodes DR, Cao X, Wang L, Dhanasekaran SM, KalyanaSundaram S, Wei JT, Rubin MA, Pienta KJ, Shah RB, Chinnaiyan AM. Integrative molecular concept modeling of prostate cancer progression. Nat Genet. 2007;39:41-51.

46. Coviello AD, Haring R, Wellons M, Vaidya D, Lehtimaki T, Keildson S, Lunetta KL, He C, Fornage M, Lagou V, Mangino M, Onland-Moret NC, Chen B, Eriksson J, Garcia M, Liu YM, Koster A, Lohman K, Lyytikainen LP, Petersen AK, Prescott J, Stolk L, Vandenput L, Wood AR, Zhuang WV, Ruokonen A, Hartikainen AL, Pouta A, Bandinelli S, Biffar R, Brabant G, Cox DG, Chen Y, Cummings S, Ferrucci L, Gunter MJ, Hankinson SE, Martikainen H, Hofman A, Homuth G, Illig T, Jansson JO, Johnson AD, Karasik D, Karlsson M, Kettunen J, Kiel DP, Kraft P, Liu J, Ljunggren O, Lorentzon M, Maggio M, Markus MR, Mellstrom D, Miljkovic I, Mirel D, Nelson S, Morin Papunen L, Peeters PH, Prokopenko I, Raffel L, Reincke M, Reiner AP, Rexrode K, Rivadeneira F, Schwartz SM, Siscovick D, Soranzo N, Stockl D, Tworoger S, Uitterlinden $\mathrm{AG}$, van Gils $\mathrm{CH}$, Vasan RS, Wichmann HE, Zhai G, Bhasin S, Bidlingmaier M, Chanock SJ, De Vivo I, Harris TB, Hunter DJ, Kahonen M, Liu S, Ouyang P, Spector TD, van der Schouw YT, Viikari J, Wallaschofski H, McCarthy MI, Frayling TM, Murray A, Franks S, Jarvelin MR, de Jong FH, Raitakari O, Teumer A, Ohlsson C, Murabito JM, Perry JR. A genome-wide association meta-analysis of circulating sex hormone-binding globulin reveals multiple Loci implicated in sex steroid hormone regulation. PLoS Genet. 2012;8:e1002805.

47. Qin J, Wu SP, Creighton CJ, Dai F, Xie X, Cheng CM, Frolov A, Ayala G, Lin X, Feng XH, Ittmann MM, Tsai SJ, Tsai MJ, Tsai SY. COUP-TFII inhibits TGF-beta-induced growth barrier to promote prostate tumorigenesis. Nature. 2013;493:236-40.

48. Hermann-Kleiter N, Baier G. Orphan nuclear receptor NR2F6 acts as an essential gatekeeper of Th17 CD4+ T cell effector functions. Cell Commun Signal. 2014;12:38.

49. Hermann-Kleiter N, Klepsch V, Wallner S, Siegmund K, Klepsch S, Tuzlak S, Villunger A, Kaminski S, Pfeifhofer-Obermair C, Gruber T, Wolf D, Baier G. The Nuclear Orphan Receptor NR2F6 Is a Central Checkpoint for Cancer Immune Surveillance. Cell Rep. 2015;12:2072-85.

50. Giguere V, Yang N, Segui P, Evans RM. Identification of a new class of steroid hormone receptors. Nature. 1988;331:91-4.

51. Giguere V. To ERR in the estrogen pathway. Trends Endocrinol Metab. 2002;13:220-5.

52. Teyssier C, Bianco S, Lanvin O, Vanacker JM. The orphan receptor ERRalpha interferes with steroid signaling. Nucleic Acids Res. 2008;36:5350-61.

53. Giguere V. Transcriptional control of energy homeostasis by the estrogen-related receptors. Endocr Rev. 2008;29:677-96.

54. Hanahan D, Weinberg RA. Hallmarks of cancer: the next generation. Cell. 2011;144:646-74.

55. Tam IS, Giguere V. There and back again: The journey of the estrogen-related receptors in the cancer realm. J Steroid Biochem Mol Biol. 2016;157:13-9. 
56. Ao A, Wang H, Kamarajugadda S, Lu J. Involvement of estrogen-related receptors in transcriptional response to hypoxia and growth of solid tumors. Proc Natl Acad Sci U S A. 2008;105:7821-6.

57. Zou C, Yu S, Xu Z, Wu D, Ng CF, Yao X, Yew DT, Vanacker JM, Chan FL. ERRalpha augments HIF-1 signalling by directly interacting with HIF-1alpha in normoxic and hypoxic prostate cancer cells. J Pathol. 2014;233:61-73.

58. Zadra G, Photopoulos C, Loda M. The fat side of prostate cancer. Biochim Biophys Acta. 2013;1831:1518-32.

59. Wilson DM, Kurhanewicz J. Hyperpolarized 13C MR for molecular imaging of prostate cancer. J Nucl Med. 2014;55:1567-72.

60. Audet-Walsh E, Papadopoli DJ, Gravel SP, Yee T, Bridon G, Caron M, Bourque G, Giguere V, St-Pierre J. The PGC-1alpha/ERRalpha Axis Represses One-Carbon Metabolism and Promotes Sensitivity to Anti-folate Therapy in Breast Cancer. Cell Rep. 2016;14:920-31.

61. Tennakoon JB, Shi Y, Han JJ, Tsouko E, White MA, Burns AR, Zhang A, Xia X, Ilkayeva OR, Xin L, Ittmann MM, Rick FG, Schally AV, Frigo DE. Androgens regulate prostate cancer cell growth via an AMPK-PGC-1alpha-mediated metabolic switch. Oncogene. 2014;33:5251-61.

62. Li Y, He L, Zeng N, Sahu D, Cadenas E, Shearn C, Li W, Stiles BL. Phosphatase and tensin homolog deleted on chromosome 10 (PTEN) signaling regulates mitochondrial biogenesis and respiration via estrogen-related receptor alpha (ERRalpha). J Biol Chem. 2013;288:25007-24.

63. Deblois G, St-Pierre J, Giguere V. The PGC-1/ERR signaling axis in cancer. Oncogene. 2013;32:3483-90.

64. Cheung CP, Yu S, Wong KB, Chan LW, Lai FM, Wang X, Suetsugi M, Chen S, Chan FL. Expression and functional study of estrogen receptor-related receptors in human prostatic cells and tissues. J Clin Endocrinol Metab. 2005;90:1830-44.

65. Fujimura T, Takahashi S, Urano T, Kumagai J, Ogushi T, Horie-Inoue K, Ouchi Y, Kitamura T, Muramatsu M, Inoue S. Increased expression of estrogen-related receptor alpha (ERRalpha) is a negative prognostic predictor in human prostate cancer. Int $J$ Cancer. 2007;120:2325-30.

66. Yang C, Zhou D, Chen S. Modulation of aromatase expression in the breast tissue by ERR $\alpha-1$ orphan receptor. Cancer Research. 1998;58:5695-700.

67. Kraus RJ, Ariazi EA, Farrell ML, Mertz JE. Estrogen-related receptor alpha 1 actively antagonizes estrogen receptor-regulated transcription in MCF-7 mammary cells. J Biol Chem. 2002;277:24826-34.

68. Deblois G, Hall JA, Perry MC, Laganiere J, Ghahremani M, Park M, Hallett M, Giguere V. Genome-wide identification of direct target genes implicates estrogenrelated receptor alpha as a determinant of breast cancer heterogeneity. Cancer Res. 2009;69:6149-57.

69. Sailland J, Tribollet V, Forcet C, Billon C, Barenton B, Carnesecchi J, Bachmann A, Gauthier KC, Yu S, Giguere V, Chan FL, Vanacker JM. Estrogen-related receptor alpha decreases RHOA stability to induce orientated cell migration. Proc Natl Acad Sci U S A. 2014;111:15108-13. 
70. Stein RA, Gaillard S, McDonnell DP. Estrogen-related receptor alpha induces the expression of vascular endothelial growth factor in breast cancer cells. J Steroid Biochem Mol Biol. 2009;114:106-12.

71. Fradet A, Sorel H, Bouazza L, Goehrig D, Depalle B, Bellahcene A, Castronovo V, Follet H, Descotes F, Aubin JE, Clezardin P, Bonnelye E. Dual function of ERRalpha in breast cancer and bone metastasis formation: implication of VEGF and osteoprotegerin. Cancer Res. 2011;71:5728-38.

72. Mori T, Sawada M, Kuroboshi H, Tatsumi H, Katsuyama M, Iwasaku K, Kitawaki J. Estrogen-related receptor alpha expression and function are associated with vascular endothelial growth factor in human cervical cancer. Int J Gynecol Cancer. 2011;21:60915.

73. Sumi D, Ignarro LJ. Estrogen-related receptor alpha 1 up-regulates endothelial nitric oxide synthase expression. Proc Natl Acad Sci U S A. 2003;100:14451-6.

74. Fisher KW, Das B, Kortum RL, Chaika OV, Lewis RE. Kinase suppressor of ras 1 (KSR1) regulates PGC1alpha and estrogen-related receptor alpha to promote oncogenic Ras-dependent anchorage-independent growth. Mol Cell Biol. 2011;31:2453-61.

75. Fujimura T, Takahashi S, Urano T, Ijichi N, Ikeda K, Kumagai J, Murata T, Takayama K, Horie-Inoue K, Ouchi Y, Muramatsu M, Homma Y, Inoue S. Differential expression of estrogen-related receptors beta and gamma (ERRbeta and ERRgamma) and their clinical significance in human prostate cancer. Cancer Sci. 2010;101:646-51.

76. Yu S, Wang X, Ng CF, Chen S, Chan FL. ERRgamma suppresses cell proliferation and tumor growth of androgen-sensitive and androgen-insensitive prostate cancer cells and its implication as a therapeutic target for prostate cancer. Cancer Res. 2007;67:4904-14.

77. Yu S, Wong YC, Wang XH, Ling MT, Ng CF, Chen S, Chan FL. Orphan nuclear receptor estrogen-related receptor-beta suppresses in vitro and in vivo growth of prostate cancer cells via p21(WAF1/CIP1) induction and as a potential therapeutic target in prostate cancer. Oncogene. 2008;27:3313-28.

78. Mohan HM, Aherne CM, Rogers AC, Baird AW, Winter DC, Murphy EP. Molecular pathways: the role of NR4A orphan nuclear receptors in cancer. Clin Cancer Res. 2012;18:3223-8.

79. Beard JA, Tenga A, Chen T. The interplay of NR4A receptors and the oncogene-tumor suppressor networks in cancer. Cell Signal. 2015;27:257-66.

80. Safe S, Kim K, Li X, Lee S-O. NR4A orphan receptors and cancer. Nucl Recept Signal, 2011, 9: e002.

81. Hedrick E, Lee SO, Doddapaneni R, Singh M, Safe S. Nuclear receptor 4A1 as a drug target for breast cancer chemotherapy. Endocr Relat Cancer. 2015;22:831-40.

82. Lee SO, Chintharlapalli S, Liu S, Papineni S, Cho SD, Yoon K, Safe S. p21 expression is induced by activation of nuclear nerve growth factor-induced Balpha (Nur77) in pancreatic cancer cells. Mol Cancer Res. 2009;7:1169-78.

83. Yoon K, Lee SO, Cho SD, Kim K, Khan S, Safe S. Activation of nuclear TR3 (NR4A1) by a diindolylmethane analog induces apoptosis and proapoptotic genes in pancreatic cancer cells and tumors. Carcinogenesis. 2011;32:836-42.

84. Lee SO, Abdelrahim M, Yoon K, Chintharlapalli S, Papineni S, Kim K, Wang H, Safe S. Inactivation of the orphan nuclear receptor TR3/Nur77 inhibits pancreatic cancer cell and tumor growth. Cancer Res. 2010;70:6824-36. 
85. Lee SO, Andey T, Jin UH, Kim K, Singh M, Safe S. The nuclear receptor TR3 regulates mTORC1 signaling in lung cancer cells expressing wild-type p53. Oncogene. 2012;31:3265-76.

86. Lee SO, Li X, Hedrick E, Jin UH, Tjalkens RB, Backos DS, Li L, Zhang Y, Wu Q, Safe S. Diindolylmethane analogs bind NR4A1 and are NR4A1 antagonists in colon cancer cells. Mol Endocrinol. 2014;28:1729-39.

87. Hedrick E, Lee SO, Kim G, Abdelrahim M, Jin UH, Safe S, Abudayyeh A. Nuclear Receptor 4A1 (NR4A1) as a Drug Target for Renal Cell Adenocarcinoma. PLoS One. 2015;10:e0128308.

88. Zhou F, Drabsch Y, Dekker TJ, de Vinuesa AG, Li Y, Hawinkels LJ, Sheppard KA, Goumans MJ, Luwor RB, de Vries CJ, Mesker WE, Tollenaar RA, Devilee P, Lu CX, Zhu H, Zhang L, Dijke PT. Nuclear receptor NR4A1 promotes breast cancer invasion and metastasis by activating TGF-beta signalling. Nat Commun. 2014;5:3388.

89. Hedrick E, Lee SO, Doddapaneni R, Singh M, Safe S. NR4A1 Antagonists Inhibit beta1-Integrin-Dependent Breast Cancer Cell Migration. Mol Cell Biol. 2016;36:138394.

90. Zhan Y, Du X, Chen H, Liu J, Zhao B, Huang D, Li G, Xu Q, Zhang M, Weimer BC, Chen D, Cheng Z, Zhang L, Li Q, Li S, Zheng Z, Song S, Huang Y, Ye Z, Su W, Lin SC, Shen Y, Wu Q. Cytosporone B is an agonist for nuclear orphan receptor Nur77. Nat Chem Biol. 2008;4:548-56.

91. Liu JJ, Zeng HN, Zhang LR, Zhan YY, Chen Y, Wang Y, Wang J, Xiang SH, Liu WJ, Wang WJ, Chen HZ, Shen YM, Su WJ, Huang PQ, Zhang HK, Wu Q. A unique pharmacophore for activation of the nuclear orphan receptor Nur77 in vivo and in vitro. Cancer Res. 2010;70:3628-37.

92. Chen HZ, Liu QF, Li L, Wang WJ, Yao LM, Yang M, Liu B, Chen W, Zhan YY, Zhang MQ, Cai JC, Zheng ZH, Lin SC, Li BA, Wu Q. The orphan receptor TR3 suppresses intestinal tumorigenesis in mice by downregulating Wnt signalling. Gut. 2012;61:71424.

93. Wang WJ, Wang Y, Chen HZ, Xing YZ, Li FW, Zhang Q, Zhou B, Zhang HK, Zhang J, Bian XL, Li L, Liu Y, Zhao BX, Chen Y, Wu R, Li AZ, Yao LM, Chen P, Zhang Y, Tian XY, Beermann F, Wu M, Han J, Huang PQ, Lin T, Wu Q. Orphan nuclear receptor TR3 acts in autophagic cell death via mitochondrial signaling pathway. Nat Chem Biol. 2014;10:133-40.

94. Uemura H, Chang C. Antisense TR3 orphan receptor can increase prostate cancer cell viability with etoposide treatment. Endocrinology. 1998;139:2329-34.

95. $\mathrm{Mu} \mathrm{X}$, Chang C. TR3 orphan nuclear receptor mediates apoptosis through up-regulating E2F1 in human prostate cancer LNCaP cells. J Biol Chem. 2003;278:42840-5.

96. Krajewska M, Kitada S, Winter JN, Variakojis D, Lichtenstein A, Zhai D, Cuddy M, Huang X, Luciano F, Baker CH, Kim H, Shin E, Kennedy S, Olson AH, Badzio A, Jassem J, Meinhold-Heerlein I, Duffy MJ, Schimmer AD, Tsao M, Brown E, Sawyers A, Andreeff M, Mercola D, Krajewski S, Reed JC. Bcl-B expression in human epithelial and nonepithelial malignancies. Clin Cancer Res. 2008;14:3011-21.

97. Lee KW, Cobb LJ, Paharkova-Vatchkova V, Liu B, Milbrandt J, Cohen P. Contribution of the orphan nuclear receptor Nur77 to the apoptotic action of IGFBP-3. Carcinogenesis. 2007;28:1653-8. 
98. Yu L, Su YS, Zhao J, Wang H, Li W. Repression of NR4A1 by a chromatin modifier promotes docetaxel resistance in PC-3 human prostate cancer cells. FEBS Lett. 2013;587:2542-51.

99. Hamid T, Malik MT, Millar RP, Kakar SS. Protein kinase A serves as a primary pathway in activation of Nur77 expression by gonadotropin-releasing hormone in the LbetaT2 mouse pituitary gonadotroph tumor cell line. Int J Oncol. 2008;33:1055-64.

100. Wang J, Yang J, Zou Y, Huang GL, He ZW. Orphan nuclear receptor nurr1 as a potential novel marker for progression in human prostate cancer. Asian Pac J Cancer Prev. 2013;14:2023-8.

101. Schoonjans K, Dubuquoy L, Mebis J, Fayard E, Wendling O, Haby C, Geboes K, Auwerx J. Liver receptor homolog 1 contributes to intestinal tumor formation through effects on cell cycle and inflammation. Proc Natl Acad Sci U S A. 2005;102:2058-62.

102. Sidler D, Renzulli P, Schnoz C, Berger B, Schneider-Jakob S, Fluck C, Inderbitzin D, Corazza N, Candinas D, Brunner T. Colon cancer cells produce immunoregulatory glucocorticoids. Oncogene. 2011;30:2411-9.

103. Bayrer JR, Mukkamala S, Sablin EP, Webb P, Fletterick RJ. Silencing LRH-1 in colon cancer cell lines impairs proliferation and alters gene expression programs. Proc Natl Acad Sci U S A. 2015;112:2467-72.

104. Miki Y, Clyne CD, Suzuki T, Moriya T, Shibuya R, Nakamura Y, Ishida T, Yabuki N, Kitada K, Hayashi S, Sasano H. Immunolocalization of liver receptor homologue-1 (LRH-1) in human breast carcinoma: possible regulator of insitu steroidogenesis. Cancer Lett. 2006;244:24-33.

105. Wang SL, Zheng DZ, Lan FH, Deng XJ, Zeng J, Li CJ, Wang R, Zhu ZY. Increased expression of hLRH-1 in human gastric cancer and its implication in tumorigenesis. Mol Cell Biochem. 2008;308:93-100.

106. Benod C, Vinogradova MV, Jouravel N, Kim GE, Fletterick RJ, Sablin EP. Nuclear receptor liver receptor homologue 1 (LRH-1) regulates pancreatic cancer cell growth and proliferation. Proc Natl Acad Sci U S A. 2011;108:16927-31.

107. Chand AL, Pathirage N, Lazarus K, Chu S, Drummond AE, Fuller PJ, Clyne CD. Liver receptor homologue-1 expression in ovarian epithelial and granulosa cell tumours. Steroids. 2013;78:700-6.

108. Chand AL, Herridge KA, Thompson EW, Clyne CD. The orphan nuclear receptor LRH1 promotes breast cancer motility and invasion. Endocr Relat Cancer. 2010;17:965-75.

109. Simandi Z, Cuaranta-Monroy I, Nagy L. Nuclear receptors as regulators of stem cell and cancer stem cell metabolism. Semin Cell Dev Biol. 2013;24:716-23.

110. Jeong Y, Mangelsdorf DJ. Nuclear receptor regulation of stemness and stem cell differentiation. Exp Mol Med. 2009;41:525-37.

111. Heng JC, Feng B, Han J, Jiang J, Kraus P, Ng JH, Orlov YL, Huss M, Yang L, Lufkin T, Lim B, Ng HH. The nuclear receptor Nr5a2 can replace Oct4 in the reprogramming of murine somatic cells to pluripotent cells. Cell Stem Cell. 2010;6:167-74.

112. Krylova IN, Sablin EP, Moore J, Xu RX, Waitt GM, MacKay JA, Juzumiene D, Bynum JM, Madauss K, Montana V, Lebedeva L, Suzawa M, Williams JD, Williams SP, Guy RK, Thornton JW, Fletterick RJ, Willson TM, Ingraham HA. Structural analyses reveal phosphatidyl inositols as ligands for the NR5 orphan receptors SF-1 and LRH-1. Cell. 2005;120:343-55. 
113. Li Y, Choi M, Suino K, Kovach A, Daugherty J, Kliewer SA, Xu HE. Structural and biochemical basis for selective repression of the orphan nuclear receptor liver receptor homolog 1 by small heterodimer partner. Proc Natl Acad Sci U S A. 2005;102:9505-10.

114. Lee JM, Lee YK, Mamrosh JL, Busby SA, Griffin PR, Pathak MC, Ortlund EA, Moore DD. A nuclear-receptor-dependent phosphatidylcholine pathway with antidiabetic effects. Nature. 2011;474:506-10.

115. Busby S, Nuhant P, Cameron M, Mercer BA, Hodder P, Roush WR, Griffin PR. Discovery of Inverse Agonists for the Liver Receptor Homologue-1 (LRH1; NR5A2). Probe Reports from the NIH Molecular Libraries Program [Internet]. 2010.

116. Benod C, Carlsson J, Uthayaruban R, Hwang P, Irwin JJ, Doak AK, Shoichet BK, Sablin EP, Fletterick RJ. Structure-based discovery of antagonists of nuclear receptor LRH-1. J Biol Chem. 2013;288:19830-44.

117. Corzo CA, Mari Y, Chang MR, Khan T, Kuruvilla D, Nuhant P, Kumar N, West GM, Duckett DR, Roush WR, Griffin PR. Antiproliferation activity of a small molecule repressor of liver receptor homolog 1. Mol Pharmacol. 2015;87:296-304.

118. Xiao L, Yu S, Hsiao WWL, Chan FL. Abstract 4771: Regulatory role of an orphan nuclear receptor LRH-1 in castration-resistant growth of prostate cancer cells. Cancer Research. 2013;73:4771.

119. Chen F, Cooney AJ, Wang Y, Law SW, O'Malley BW. Cloning of a novel orphan receptor (GCNF) expressed during germ cell development. Mol Endocrinol. 1994;8:1434-44.

120. Susens U, Borgmeyer U. Characterization of the human germ cell nuclear factor gene. Biochim Biophys Acta. 1996;1309:179-82.

121. Wang Q, Cooney AJ. Revisiting the role of GCNF in embryonic development. Semin Cell Dev Biol. 2013;24:679-86.

122. Juric D, Sale S, Hromas RA, Yu R, Wang Y, Duran GE, Tibshirani R, Einhorn LH, Sikic BI. Gene expression profiling differentiates germ cell tumors from other cancers and defines subtype-specific signatures. Proc Natl Acad Sci U S A. 2005;102:17763-8.

123. Mathieu R, Evrard B, Fromont G, Rioux-Leclercq N, Godet J, Cathelineau X, Guille F, Primig M, Chalmel F. Expression screening of cancer/testis genes in prostate cancer identifies NR6A1 as a novel marker of disease progression and aggressiveness. Prostate. 2013;73:1103-14.

124. Kawajiri K, Ikuta T, Suzuki T, Kusaka M, Muramatsu M, Fujieda K, Tachibana M, Morohashi K. Role of the LXXLL-motif and activation function 2 domain in subcellular localization of Dax-1 (dosage-sensitive sex reversal-adrenal hypoplasia congenita critical region on the X chromosome, gene 1). Mol Endocrinol. 2003;17:9941004.

125. Agoulnik IU, Krause WC, Bingman WE, 3rd, Rahman HT, Amrikachi M, Ayala GE, Weigel NL. Repressors of androgen and progesterone receptor action. J Biol Chem. 2003;278:31136-48.

126. Iyer AK, McCabe ER. Molecular mechanisms of DAX1 action. Mol Genet Metab. 2004;83:60-73.

127. Oda T, Tian T, Inoue M, Ikeda J, Qiu Y, Okumura M, Aozasa K, Morii E. Tumorigenic role of orphan nuclear receptor NR0B1 in lung adenocarcinoma. Am J Pathol. 2009;175:1235-45. 
128. Garcia-Aragoncillo E, Carrillo J, Lalli E, Agra N, Gomez-Lopez G, Pestana A, Alonso J. DAX1, a direct target of EWS/FLI1 oncoprotein, is a principal regulator of cell-cycle progression in Ewing's tumor cells. Oncogene. 2008;27:6034-43.

129. Kinsey M, Smith R, Iyer AK, McCabe ERB, Lessnick SL. EWS/FLI and Its Downstream Target NR0B1 Interact Directly to Modulate Transcription and Oncogenesis in Ewing's Sarcoma. Cancer Research. 2009;69:9047-55.

130. Jiang HL, Xu D, Yu H, Ma X, Lin GF, Ma DY, Jin JZ. DAX-1 inhibits hepatocellular carcinoma proliferation by inhibiting beta-catenin transcriptional activity. Cell Physiol Biochem. 2014;34:734-42.

131. Holter E, Kotaja N, Makela S, Strauss L, Kietz S, Janne OA, Gustafsson JA, Palvimo JJ, Treuter E. Inhibition of androgen receptor (AR) function by the reproductive orphan nuclear receptor DAX-1. Mol Endocrinol. 2002;16:515-28.

132. Lee MY, Lu A, Gudas LJ. Transcriptional regulation of Rex1 (zfp42) in normal prostate epithelial cells and prostate cancer cells. J Cell Physiol. 2010;224:17-27.

133. Nakamura Y, Suzuki T, Arai Y, Sasano H. Nuclear receptor DAX1 in human prostate cancer: a novel independent biological modulator. Endocr J. 2009;56:39-44.

134. Tong SJ, Liu J, Wang X, Qu LX. microRNA-181 promotes prostate cancer cell proliferation by regulating DAX-1 expression. Exp Ther Med. 2014;8:1296-300.

135. Zhang H, Thomsen JS, Johansson L, Gustafsson JA, Treuter E. DAX-1 functions as an LXXLL-containing corepressor for activated estrogen receptors. $J$ Biol Chem. 2000;275:39855-9.

136. Zhang Y, Hagedorn CH, Wang L. Role of nuclear receptor SHP in metabolism and cancer. Biochim Biophys Acta. 2011;1812:893-908.

137. Xiao J, Gong AY, Eischeid AN, Chen D, Deng C, Young CY, Chen XM. miR-141 modulates androgen receptor transcriptional activity in human prostate cancer cells through targeting the small heterodimer partner protein. Prostate. 2012;72:1514-22.

138. Dawson MI, Xia Z, Liu G, Ye M, Fontana JA, Farhana L, Patel BB, Arumugarajah S, Bhuiyan M, Zhang XK, Han YH, Stallcup WB, Fukushi J, Mustelin T, Tautz L, Su Y, Harris DL, Waleh N, Hobbs PD, Jong L, Chao WR, Schiff LJ, Sani BP. An adamantylsubstituted retinoid-derived molecule that inhibits cancer cell growth and angiogenesis by inducing apoptosis and binds to small heterodimer partner nuclear receptor: effects of modifying its carboxylate group on apoptosis, proliferation, and protein-tyrosine phosphatase activity. J Med Chem. 2007;50:2622-39.

139. Chandrasekar T, Yang JC, Gao AC, Evans CP. Mechanisms of resistance in castrationresistant prostate cancer (CRPC). Transl Androl Urol. 2015;4:365-80.

140. Yu S, Jia L, Zhang Y, Wu D, Xu Z, Ng CF, To KK, Huang Y, Chan FL. Increased expression of activated endothelial nitric oxide synthase contributes to antiandrogen resistance in prostate cancer cells by suppressing androgen receptor transactivation. Cancer Lett. 2013;328:83-94.

141. Davis JN, Wojno KJ, Daignault S, Hofer MD, Kuefer R, Rubin MA, Day ML. Elevated E2F1 inhibits transcription of the androgen receptor in metastatic hormone-resistant prostate cancer. Cancer Res. 2006;66:11897-906.

142. Valdez CD, Kunju L, Daignault S, Wojno KJ, Day ML. The E2F1/DNMT1 axis is associated with the development of AR negative castration resistant prostate cancer. Prostate. 2013;73:1776-85. 
143. Lakshmikanthan V, Zou L, Kim JI, Michal A, Nie Z, Messias NC, Benovic JL, Daaka Y. Identification of betaArrestin2 as a corepressor of androgen receptor signaling in prostate cancer. Proc Natl Acad Sci U S A. 2009;106:9379-84.

144. Wang J, Zou JX, Xue X, Cai D, Zhang Y, Duan Z, Xiang Q, Yang JC, Louie MC, Borowsky AD, Gao AC, Evans CP, Lam KS, Xu J, Kung HJ, Evans RM, Xu Y, Chen HW. ROR-gamma drives androgen receptor expression and represents a therapeutic target in castration-resistant prostate cancer. Nat Med. 2016;22:488-96.

145. Mu X, Yang L, Chang C. Stage dependent and androgen inductive expression of orphan receptor TR4 in rat testis. Biochem Biophys Res Commun. 2006;341:464-9.

146. Lee YF, Shyr CR, Thin TH, Lin WJ, Chang C. Convergence of two repressors through heterodimer formation of androgen receptor and testicular orphan receptor-4: a unique signaling pathway in the steroid receptor superfamily. Proc Natl Acad Sci USA. 1999;96:14724-9.

147. Miao L, Shi J, Wang CY, Zhu Y, Du X, Jiao H, Mo Z, Klocker H, Lee C, Zhang J. Estrogen receptor-related receptor alpha mediates up-regulation of aromatase expression by prostaglandin E2 in prostate stromal cells. Mol Endocrinol. 2010;24:1175-86.

148. Lanzino M, Maris P, Sirianni R, Barone I, Casaburi I, Chimento A, Giordano C, Morelli C, Sisci D, Rizza P, Bonofiglio D, Catalano S, Ando S. DAX-1, as an androgen-target gene, inhibits aromatase expression: a novel mechanism blocking estrogen-dependent breast cancer cell proliferation. Cell Death Dis. 2013;4:e724.

149. Yuan X, Lu ML, Li T, Balk SP. SRY interacts with and negatively regulates androgen receptor transcriptional activity. J Biol Chem. 2001;276:46647-54.

150. Gobinet J, Auzou G, Nicolas JC, Sultan C, Jalaguier S. Characterization of the interaction between androgen receptor and a new transcriptional inhibitor, SHP. Biochemistry. 2001;40:15369-77.

151. Gobinet J, Carascossa S, Cavailles V, Vignon F, Nicolas JC, Jalaguier S. SHP represses transcriptional activity via recruitment of histone deacetylases. Biochemistry. 2005;44:6312-20.

152. Jouravel N, Sablin E, Arnold LA, Guy RK, Fletterick RJ. Interaction between the androgen receptor and a segment of its corepressor SHP. Acta Crystallogr D Biol Crystallogr. 2007;63:1198-200.

153. Zhou XE, Suino-Powell KM, Xu Y, Chan CW, Tanabe O, Kruse SW, Reynolds R, Engel JD, Xu HE. The orphan nuclear receptor TR4 is a vitamin A-activated nuclear receptor. J Biol Chem. 2011;286:2877-85.

154. Benod C, Villagomez R, Filgueira CS, Hwang PK, Leonard PG, Poncet-Montange G, Rajagopalan S, Fletterick RJ, Gustafsson JA, Webb P. The human orphan nuclear receptor tailless (TLX, NR2E1) is druggable. PLoS One. 2014;9:e99440.

155. Kruse SW, Suino-Powell K, Zhou XE, Kretschman JE, Reynolds R, Vonrhein C, Xu Y, Wang L, Tsai SY, Tsai MJ, Xu HE. Identification of COUP-TFII orphan nuclear receptor as a retinoic acid-activated receptor. PLoS Biol. 2008;6:e227.

156. Nuclear Receptors Nomenclature Committee. A unified nomenclature system for the nuclear receptor superfamily. Cell. 1999;97:161-3. 


\section{Figure legends}

Figure 1. Classification of NRs. According to their ligand dependence, nuclear receptors are classified as hormone receptors, adopted orphan receptors and orphan receptors.

Figure 2. Involvement of TLX in prostate cancer progression. Oncogenic stress, such as $\mathrm{Ras}^{\mathrm{G} 12 \mathrm{~V}}$ mutation or PTEN loss, can induce premature senescence, which is an important tumor-suppressing mechanism to prevent both premalignant transformation and cancer progression. TLX can act as a promoter of prostate carcinogenesis by suppressing oncogeneinduced senescence via its transcriptional regulation of two senescence-associated genes, repression of CDKN1A (p21) and transactivation of SIRT1. TLX can also form a regulatory loop with a polycomb group protein CBX7 and mediate the suppression of oncogene-induced senescence.

Figure 3. Regulation of energy metabolism by ERRs in cancer. (A) ERR $\alpha$ can cooperate with several oncogenic signaling pathways to modulate or promote the metabolic reprogramming in cancer cells. Via interaction with certain oncoproteins, such as c-Myc, mTOR or HIF-1, ERR $\alpha$ can synergistically promote the expressions of some key metabolic regulators, including genes encoding glucose transporter (Glut1), enzymes involved in glycolysis and lipid biosynthesis. Her2/IGF-1 signaling pathways can enhance PGC-1 $\beta$ expression to activate the ERR $\alpha / \mathrm{PGC}-1$ complex. The ERR $\alpha / \mathrm{PGC}-1$ signaling axis, which can also be activated by the energy sensor AMPK via AR and PTEN/PI3K/AKT signaling, contributes to metabolic reprogramming in cancer cells. The ERR $\gamma / \mathrm{PGC}-1 \beta$ signaling axis can regulate metabolic genes more favoring on oxidative metabolism rather than glycolysis, and with this effect further enhanced by HIF-1 $\alpha$ or hypoxia. (B) Hypoxic adaptation is an important hallmark of cancer cells, through which to facilitate their malignant growth and advanced development. ERR $\alpha$ can promote the hypoxic growth adaptation of prostate cancer cells via a protective interaction with HIF-1 $\alpha$. Through this interaction, it can help to prevent HIF-1 $\alpha$ from ubiquitin degradation and also to promote synergistically the expression of both 
ERR $\alpha$ and HIF-1 $\alpha$ common target genes involved in energy metabolism and angiogenesis. HRE, HIF responsive element; ERRE, ERR responsive element.

Figure 4. Cancer cell death or survival mediated by NGFI-B. (A) Pro-apoptotic function of NGFI-B. NGFI-B can promote apoptosis in cancer cells via its translocation from nucleus to mitochondria, where it triggers mitochondrial membrane permeabilization and induces cytochrome c release. In mitochondria, NGFI-B interacts with Bcl-1, Bcl-B and Bfl-1 to induce their conformational changes, thereby converting their anti-apoptotic function to be pro-apoptotic. NGFI-B-mediated cell death can be suppressed by certain oncogenic signalings: interaction with chromodomain helicase DNA binding protein 1-like (CHD1L) or nuclear receptor SHP resulted in inhibition of its nucleus-to-mitochondria translocation; phosphorylation by Akt resulted in inhibition of its transcriptional activity and mitochondria targeting. The interplay between NGFI-B and Wnt signaling pathway can disrupt the association of $\beta$-catenin with TCF-4 and recruitment of transcriptional co-repressors to the promoters of Wnt targets. Disturbance of Semaphorin 3E (Sema3E)/Plexin D1 association by Plexin D1 ligand can trap the triggered NGFI-B-dependent apoptosis. Some NGFI-B agonists, such as Csn-B, THPN and the C-DIM compounds, are shown to be potent and effective antitumor agents. (B) Anti-apoptotic function of NGFI-B and mechanisms of apoptosis induction by NGFI-B inactivation. NGFI-B is upregulated in many cancers, where it plays oncogenic roles by interacting with some oncoproteins (e.g. HIF-1 $\alpha$, Pin1) and binding to the promoters of some anti-apoptotic genes. Some C-DIM analogs are proved to be NGFI-B antagonists, similar to siNGFI-B and promote apoptosis to inhibit tumor growth and migration through mechanisms, including induction of p53-mTOR signaling, endoplasmic reticulum (ER) stress and/or disturbance of NGFI-B-Sp1-p300 DNA binding complex on the GC-rich promoters of genes involved in survival. NBRE, NGFI-B responsive element. Reviews on NGFI-Bmediated pathways refer to references $7,84-86$. 
Figure 5. Working model of LRH-1 in the regulation of key enzyme genes in androgen synthesis in prostate cancer. Prostate cancer cells can de novo synthesize small amounts of androgens directly from cholesterol through the sequential actions of steroidogenic enzymes in the steroidogenic pathway that is normally active in the testes and adrenal glands. Some of these key enzymatic genes can be transcriptionally activated by LRH-1 in a direct (CYP17A1) or indirect (StAR, CYP11A1, HSD3B1/2 and AKR1C3) manner and thus contribute to the increase of intratumoral androgen concentration in cancer cells, resulted in activation of AR signaling in prostate cancer cells even under castration, and thus promoting castrationresistant growth of prostate cancer cells.

Figure 6. Interaction of orphan NRs with AR signaling pathway. (A) ROR $\gamma$ can promote AR expression through binding to the first exon of AR gene with variant ROR binding element (RORE) and recruiting coregulators SRCs. (B) TR4 forms a heterodimer with AR to repress the expression of both the TR4 and AR target genes. (C) COUP-TFII interacts with $\mathrm{AR}$ and represses $\mathrm{AR}$ transactivation by inhibiting $\mathrm{AR}$ recruitment to its target gene promoters and also by competing with AR coactivators. (D) ERR $\alpha$ regulates the activity of androgen-responsive element (ARE)-containing promoters with its coactivator PGC-1 $\alpha$. (E) The mechanisms of SHP- and DAX1-mediated repression on AR are different despite of their significant similarity sequence in the LBD. DAX-1 interferes with the dimerization and interdomain communication of the AR and prevents its translocation to nucleus. However, SHP inhibits the transcriptional activity of AR by competing with the AR coactivators or recruiting of histone deacetylase 1 (HDAC1). 
Nuclear receptor superfamily (48)

Hormone receptors (12)

-High-affinity lipophilic hormones

\begin{tabular}{|lll|}
\hline 1A & TRa, $\beta$ & Thyroid hormones \\
1B & RARa, $\beta, Y$ & Retinoic acids \\
1I & VDR & Vitamin D \\
& & \\
3A & ER $\alpha, \beta$ & Estrogen \\
3C & GR & Glucocorticoid \\
& MR & Mineralocorticoid \\
& PR & Progesterone \\
& AR & Androgen \\
& & \\
& & \\
& & \\
& \\
& \\
& \\
\end{tabular}

Adopted orphan receptors (11) -Low-affinity ligands

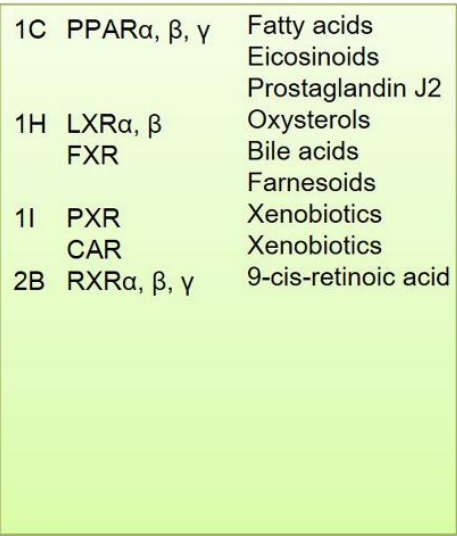

Figure 1
Orphan receptors (25)

-Constitutive active /unknown ligands

\begin{tabular}{|ll|}
\hline 1D & Rev-Erba, $\beta$ \\
1F & RORa, $\beta, \mathrm{Y}$ \\
2A & HNF4 $\alpha, \mathrm{Y}$ \\
2C & TR2, 4 \\
2E & TLX \\
& PNR \\
2F & COUP-TFI, II \\
& EAR2 \\
3B & ERRa, $\beta, \mathrm{Y}$ \\
4A & NGFI-B \\
& NURR1 \\
& NOR1 \\
5A & SF1 \\
& LRH-1 \\
6A & GCNF \\
OB & DAX1 \\
& SHP \\
& \\
\hline
\end{tabular}




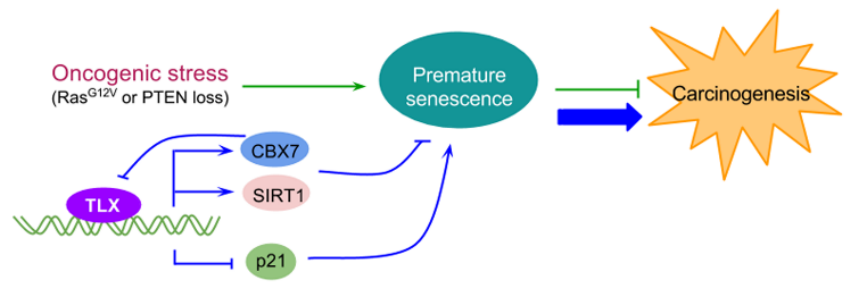

Figure 2 
A

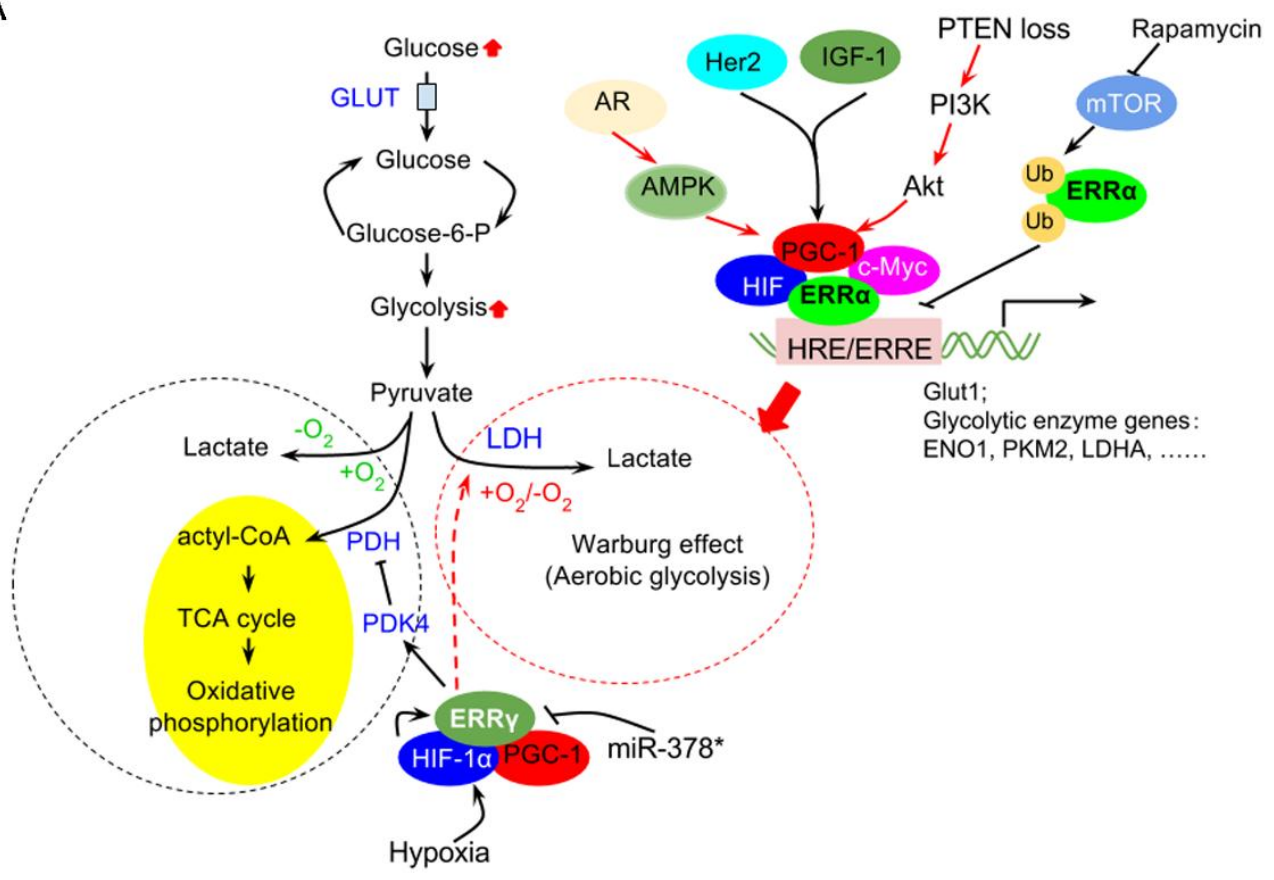

B

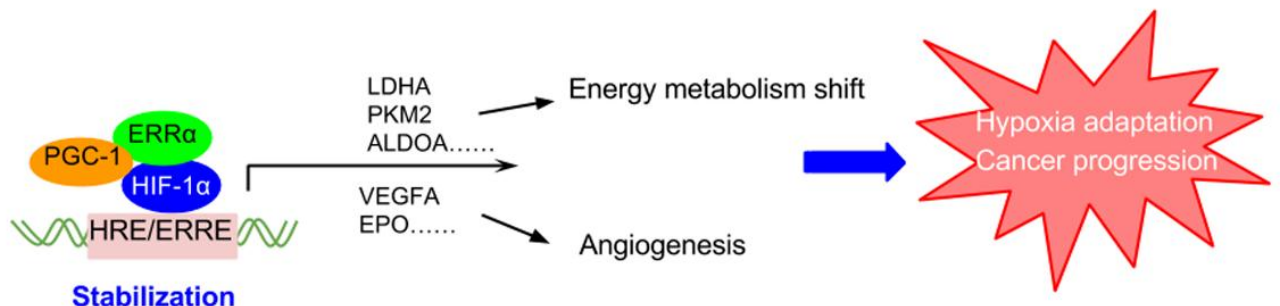

Figure 3 


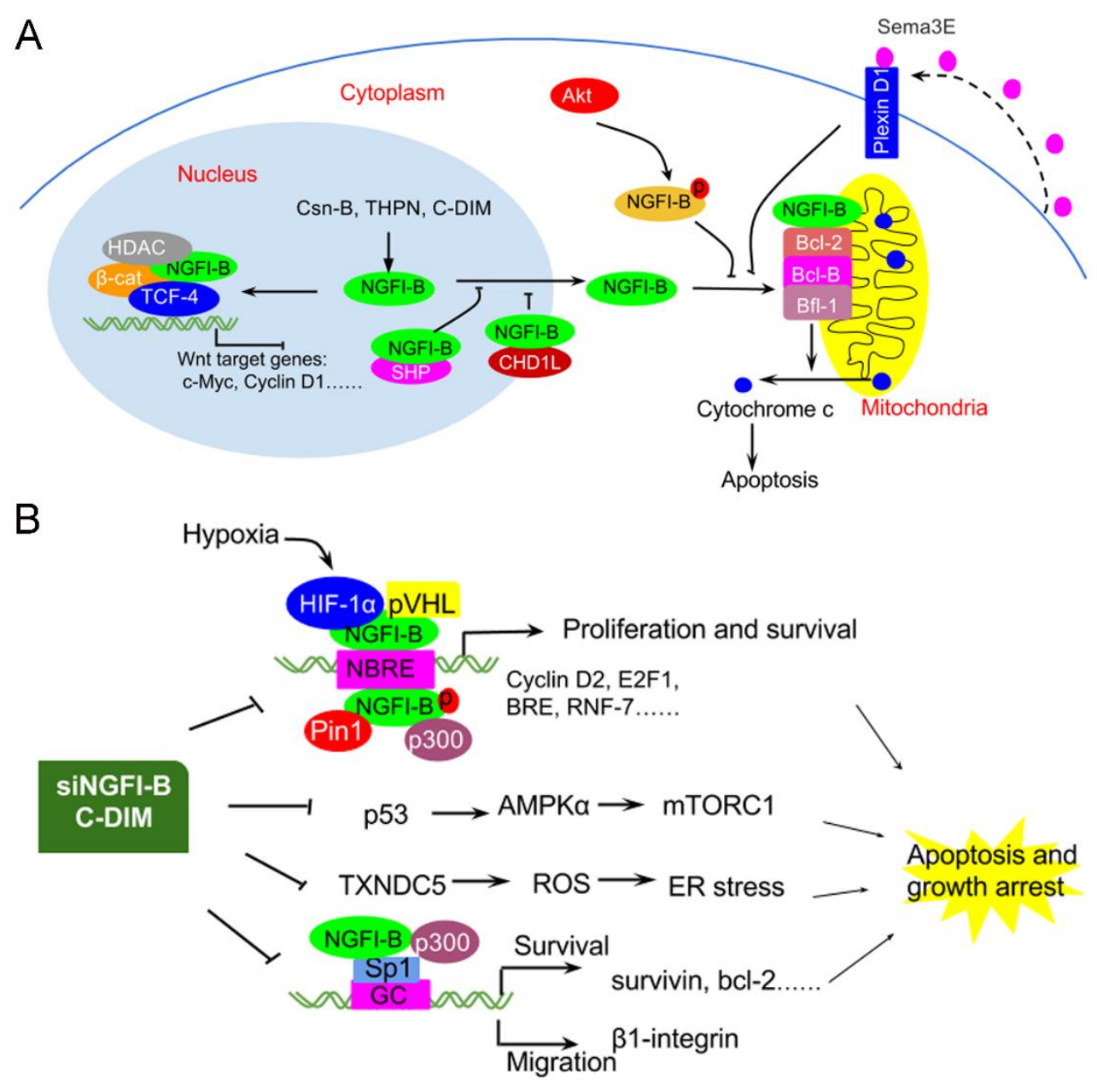

Figure 4 

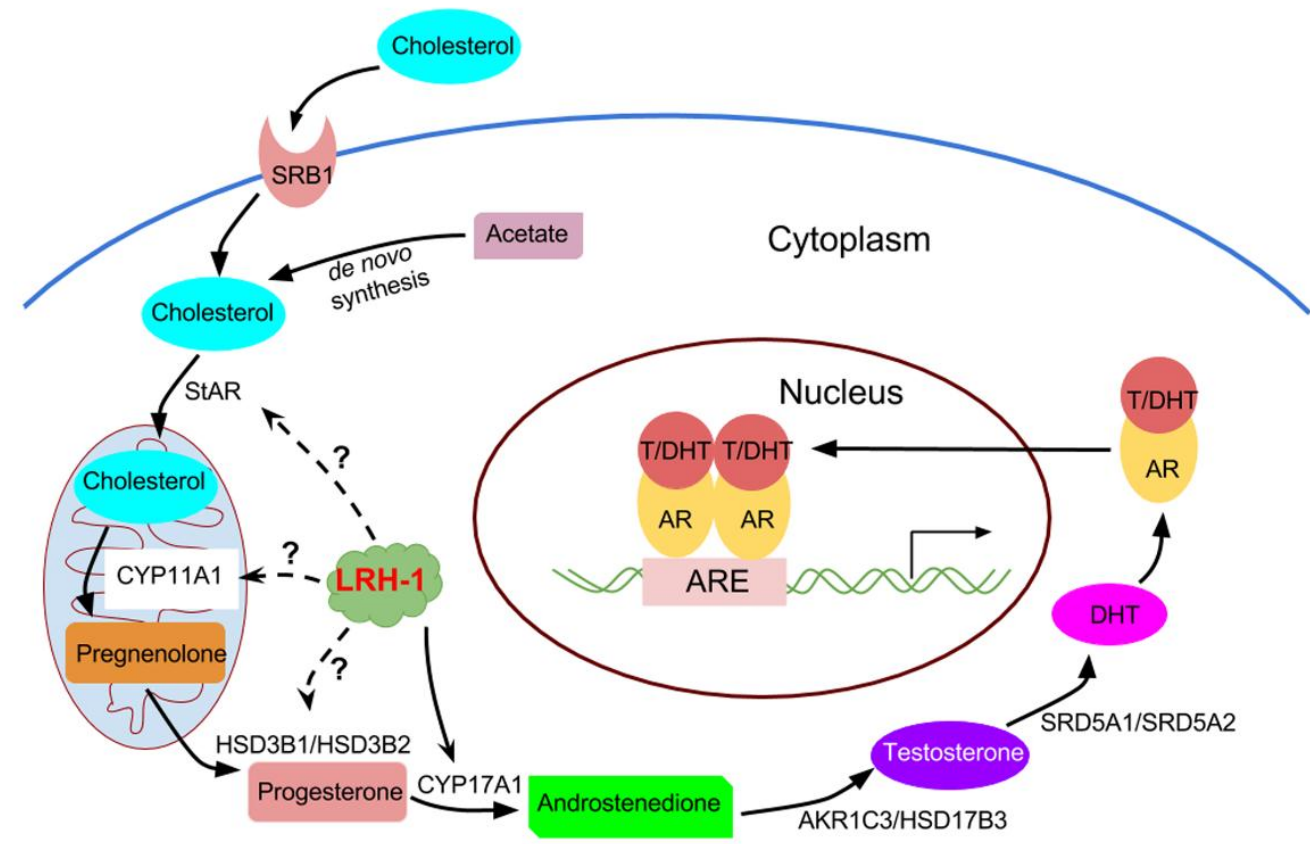

Figure 5 
A

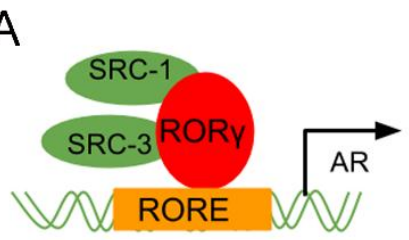

B

B

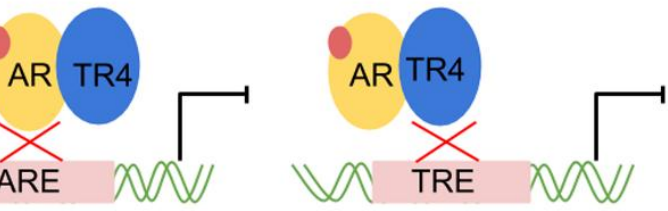

C

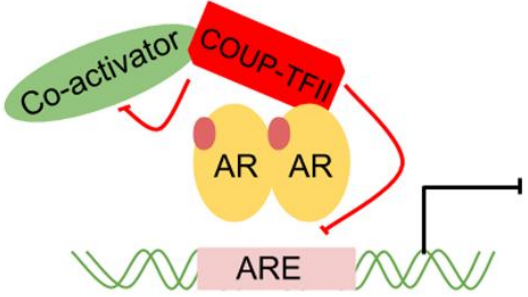

D

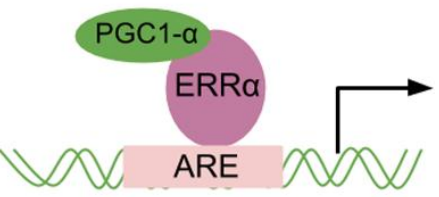

E

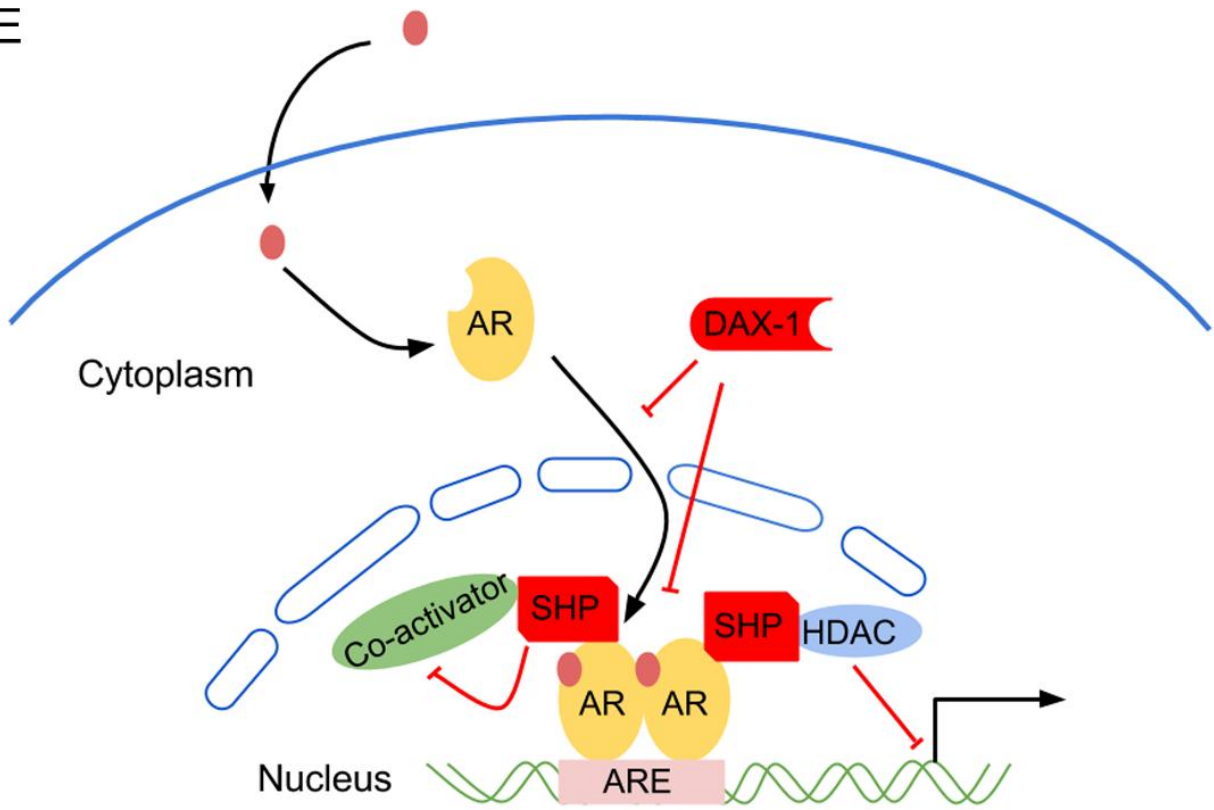

Figure 6 
Table 1. Orphan NRs in prostate cancer

\begin{tabular}{|c|c|c|c|c|c|}
\hline $\begin{array}{l}\text { Gene } \\
\text { names }\end{array}$ & $\begin{array}{l}\text { Common } \\
\text { names }\end{array}$ & $\begin{array}{c}\text { Selected } \\
\text { molecules }\end{array}$ & Expression patterns in prostate cancer & $\begin{array}{l}\text { Characterized functions in prostate and } \\
\text { prostate cancer }\end{array}$ & $\begin{array}{c}\text { Reference } \\
\text { s }\end{array}$ \\
\hline NR1F3 & RORy & $\begin{array}{l}\text { SR2211; } \\
\text { XY018; } \\
\text { XY011 }\end{array}$ & $\begin{array}{l}\text { Significantly upregulated in metastatic } \\
\text { prostate cancer }\end{array}$ & Promotes AR expression. & (144) \\
\hline$N R 2 C 1$ & TR2 & Unknown & Not characterized & $\begin{array}{l}\text { 1. Suppresses AR-mediated transactivation; } \\
\text { 2. Expression of TR2 can be suppressed by } \\
\text { androgen }\end{array}$ & $(14,15)$ \\
\hline$N R 2 C 2$ & TR4 & $\begin{array}{l}\text { Retinol; } \\
\text { retinoic acid }\end{array}$ & $\begin{array}{l}\text { 1. Positively correlated with Gleason score; } \\
\text { 2. Highly expressed in prostate cancer } \\
\text { CD } 133^{+} \text {stem/progenitor cells compared } \\
\text { with CD } 133^{-} \text {cells; } \\
\text { 3. Highly expressed in biochemical } \\
\text { recurrence patients after brachytherapy. }\end{array}$ & $\begin{array}{l}\text { 1. Suppresses AR-mediated transactivation; } \\
\text { 2. Regulate chemoresistance of prostate } \\
\text { cancer } \mathrm{CD} 133^{+} \text {stem/progenitor cells; } \\
\text { 3. Promotes prostate cancer metastasis via } \\
\text { upregulation of } \mathrm{CCL} 2 / \mathrm{CCR} 2 \text {; } \\
\text { 4. Enhance radio-resistance. }\end{array}$ & $\begin{array}{l}(19-21 \\
146,153)\end{array}$ \\
\hline NR2E1 & TLX & $\begin{array}{l}\text { Famprofazone; } \\
\text { 1-(1,5- } \\
\text { dimethylpyrazole } \\
\text {-3-carbonyl)-4- } \\
\text { (diphenylmethyl) } \\
\text { piperazine; } \\
\text { Dydrogesterone }\end{array}$ & Positively correlated with Gleason score & $\begin{array}{l}\text { 1. Promotes prostate cancer cell growth and } \\
\text { migration } \\
\text { 2. Suppresses premature senescence by trans- } \\
\text { regulation on CDKN1A and SIRT1 genes. }\end{array}$ & $(32,154)$ \\
\hline$N R 2 F 2$ & COUP-TFII & Retinoid acids & $\begin{array}{l}\text { 1. Highly expressed in tumor cells and } \\
\text { significantly associated with cancer } \\
\text { aggressiveness; } \\
\text { 2. Serve as a predictor to stratify risk of } \\
\text { recurrence in patients; }\end{array}$ & $\begin{array}{l}\text { 1. Represses AR transactivation as an AR } \\
\text { corepressor; } \\
\text { 2. Cooperates with PTEN deletion to promote } \\
\text { prostate carcinogenesis and metastatic } \\
\text { potential via suppression of TGF- } \beta \text { - } \\
\text { dependent growth barrier. }\end{array}$ & $\begin{array}{l}(44,47, \\
155)\end{array}$ \\
\hline NR2F6 & EAR2 & Unknown & Not characterized & $\begin{array}{l}\text { Control the effector } T \text { cell-dependent anti- } \\
\text { tumor immunity by repression of key cytokines } \\
\text { in } \mathrm{CD}^{+} \text {and } \mathrm{CD}^{+} \text {effector } T \text { cells. }\end{array}$ & (49) \\
\hline NR3B1 & $\mathrm{ERR} \alpha$ & $\begin{array}{l}\text { ХCT790; } \\
\text { SR16388 }\end{array}$ & $\begin{array}{l}\text { 1. Heterogeneously expressed in low } \\
\text { Gleason grade cancer; } \\
\text { 2. Significantly higher in tumor than in } \\
\text { benign foci } \\
\text { 3. Positively correlated with the Gleason } \\
\text { score; }\end{array}$ & $\begin{array}{l}\text { 1. Cross-talk with androgen signaling pathways } \\
\text { by regulate androgen-responsive genes; } \\
\text { 2. Contributes to local estrogen production by } \\
\text { up-regulating aromatase expression in } \\
\text { response to PGE2 in prostate stromal cells; } \\
\text { 3. Promotes hypoxic adaptation via interaction }\end{array}$ & $\begin{array}{l}(52,57 \\
64,65 \\
147)\end{array}$ \\
\hline
\end{tabular}




\begin{tabular}{|c|c|c|c|c|c|}
\hline & & & & with HIF-1 $\alpha$ to inhibit HIF-1 $\alpha$ ubiquitination & \\
\hline NR3B2 & ERR $\beta$ & $\begin{array}{l}\text { Diethylstilbestrol } \\
4-\mathrm{OHT} \\
\text { GSK5182 } \\
\text { DY131 }\end{array}$ & Down-regulated in cancer lesions & $\begin{array}{l}\text { Inhibits cancer cell growth via direct control of } \\
\text { cell-cycle regulators p21 and p } 27 \text {. }\end{array}$ & $\begin{array}{l}(64,75, \\
77)\end{array}$ \\
\hline NR3B3 & ERR $\gamma$ & $\begin{array}{l}\text { Diethylstilbestrol } \\
\text { 4-OHT } \\
\text { GSK5182 } \\
\text { DY131 }\end{array}$ & $\begin{array}{l}\text { 1. Down-regulated in prostate cancer cell } \\
\text { lines and prostate cancer tissues; } \\
\text { 2. Correlated with poorer cancer-specific } \\
\text { survival. }\end{array}$ & $\begin{array}{l}\text { Inhibits cancer cell proliferation via direct control } \\
\text { of cell-cycle regulators p21 and p27. }\end{array}$ & $\begin{array}{l}(64,75, \\
76)\end{array}$ \\
\hline NR4A1 & NGFI-B & $\begin{array}{l}\text { Csn-B; } \\
\text { THPN; } \\
\text { C-DIM analogs }\end{array}$ & Not characterized & $\begin{array}{l}\text { 1. Regulates cancer cell apoptosis by } \\
\text { interacting with IGFBP-3; } \\
\text { 2. Mediated docetaxel chemoresistantce }\end{array}$ & $\begin{array}{l}(94,95 \\
97,98)\end{array}$ \\
\hline NR4A2 & NURR1 & $\begin{array}{l}\text { Benzimidazoles } \\
\text { DIM-C-pPhCl }\end{array}$ & $\begin{array}{l}\text { Higher in prostate cancer tissues than in } \\
\text { benign prostate tissue. }\end{array}$ & $\begin{array}{l}\text { Promotes cancer cell proliferation, migration and } \\
\text { invasion, and inhibits apoptosis }\end{array}$ & $(100)$ \\
\hline NR6A1 & GCNF & Unknown & $\begin{array}{l}\text { 1. Up-Regulated in Castration-Resistant } \\
\text { Prostate Cancers; } \\
\text { 2. Significantly associated with prostate } \\
\text { cancer progression and aggressiveness }\end{array}$ & Not characterized & $(123)$ \\
\hline NROB1 & DAX1 & Thiocolciran & Inversely correlated with Gleason score. & $\begin{array}{l}\text { 1. Represses AR activity; } \\
\text { 2. regulates steroid hormone production }\end{array}$ & $(131,133)$ \\
\hline NROB2 & SHP & $\begin{array}{l}\text { AHPC; } \\
\text { 3-Cl-AHPC }\end{array}$ & Down-regulated in prostate cancer cell lines. & $\begin{array}{l}\text { 1. Interact with AR and represses AR activity; } \\
\text { 2. SHP ligand inhibits prostate cancer cell } \\
\text { growth }\end{array}$ & $\begin{array}{l}(137,138, \\
152)\end{array}$ \\
\hline
\end{tabular}

Nomenclature used is based on the system defined by the NRs nomenclature committee (156). 
Orphan Nuclear Receptors

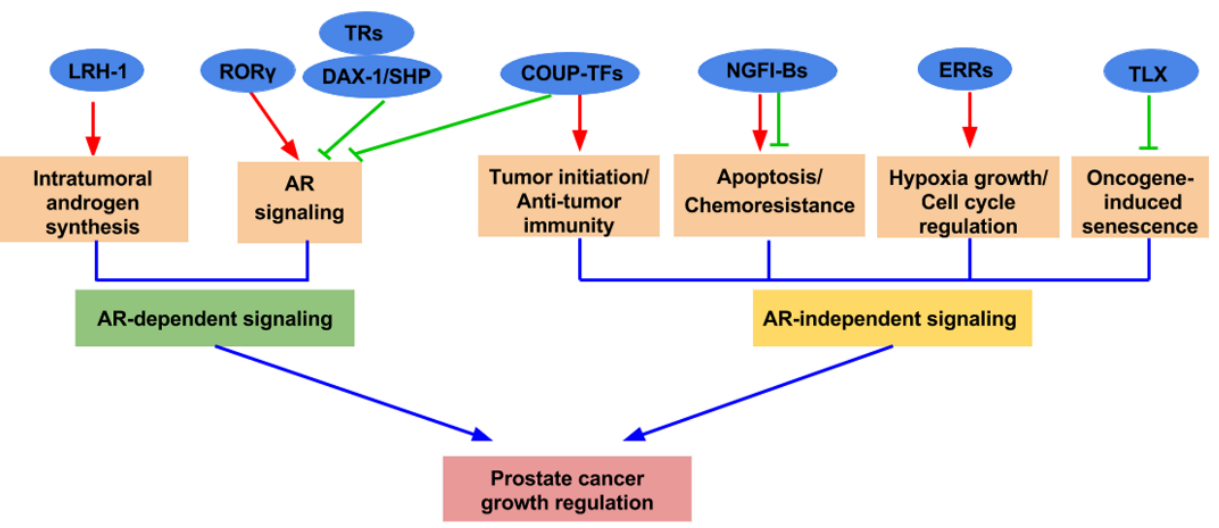

